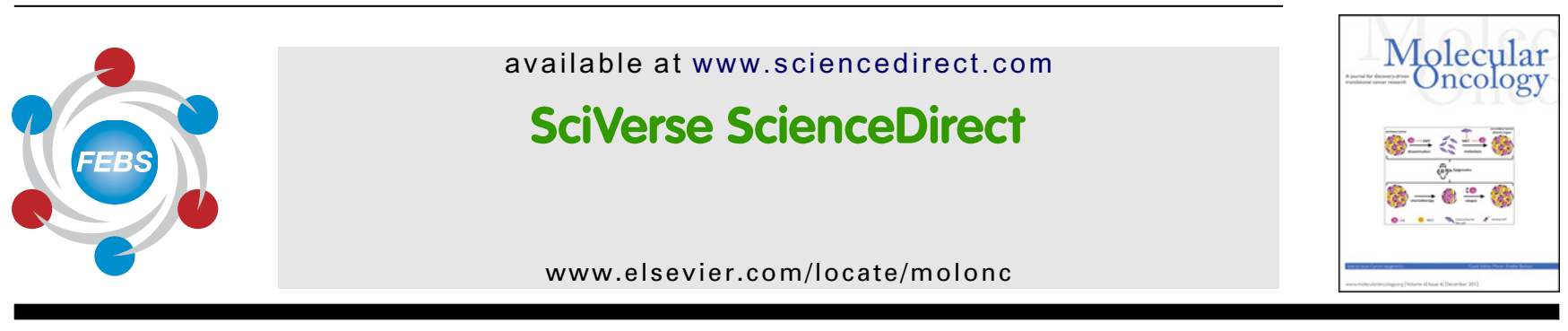

Review

\title{
MicroRNA and cancer
}

\section{Martin D. Jansson, Anders H. Lund*}

Biotech Research and Innovation Centre and Centre for Epigenetics, University of Copenhagen, Ole Maaløes Vej 5, DK-2200 Copenhagen, Denmark

\section{A R T I C L E I N F O}

Article history:

Received 23 August 2012

Accepted 30 September 2012

Available online 9 October 2012

Keywords:

MicroRNA

Cancer

Non-coding RNA

Therapy

\begin{abstract}
A B S T R A C T
With the advent of next generation sequencing techniques a previously unknown world of non-coding RNA molecules have been discovered. Non-coding RNA transcripts likely outnumber the group of protein coding sequences and hold promise of many new discoveries and mechanistic explanations for essential biological phenomena and pathologies. The best characterized non-coding RNA family consists in humans of about 1400 microRNAs for which abundant evidence have demonstrated fundamental importance in normal development, differentiation, growth control and in human diseases such as cancer. In this review, we summarize the current knowledge and concepts concerning the involvement of microRNAs in cancer, which have emerged from the study of cell culture and animal model systems, including the regulation of key cancer-related pathways, such as cell cycle control and the DNA damage response. Importantly, microRNA molecules are already entering the clinic as diagnostic and prognostic biomarkers for patient stratification and also as therapeutic targets and agents.
\end{abstract}

(c) 2012 Federation of European Biochemical Societies. Published by Elsevier B.V. All rights reserved.

\section{Introduction}

MicroRNAs (miRNAs) are short non-coding RNAs of 20-24 nucleotides that play important roles in virtually all biological pathways in mammals and other multicellular organisms. Accordingly, miRNAs influence numerous cancer-relevant processes such as proliferation, cell cycle control, apoptosis, differentiation, migration and metabolism. Although many aspects of the miRNA biogenesis pathway and repressive mechanisms are still obscure, the key processes have been characterized. For most miRNAs, primary miRNA transcripts are generated by RNA polymerase II, either as separate transcriptional units or embedded within the introns of protein coding genes. In the nucleus, the microprocessor complex containing the RNase III enzyme Drosha trims the primary transcript to release the pre-miRNA hairpin that is subsequently exported to the cytoplasm by exportin 5 (XPO5). In the cytoplasm, a protein complex including DICER and TRBP further trims the pre-miRNA to produce the single-stranded mature miRNA, which subsequently incorporates into the RNA induced silencing complex (RISC), holding key proteins such as AGO2 and GW182. The mature miRNA then induces posttranscriptional gene silencing by tethering RISC to partly complementary sequence motifs in target mRNAs predominantly found within the $3^{\prime}$ untranslated regions (UTRs) (Figure 1) (Bartel, 2009; Fabian and Sonenberg, 2012; Saj and Lai, 2011). As a single miRNA may target up to several hundred mRNAs, aberrant miRNA expression may affect a multitude of transcripts and profoundly influence cancer-related signalling pathways. Although initially described in 1993 (Lee et al., 1993;

\footnotetext{
* Corresponding author. Tel.: +45 35325657; fax: +45 35325669.

E-mail address: anders.lund@bric.ku.dk (A.H. Lund).

1574-7891/\$ - see front matter @ 2012 Federation of European Biochemical Societies. Published by Elsevier B.V. All rights reserved. http://dx.doi.org/10.1016/j.molonc.2012.09.006
} 

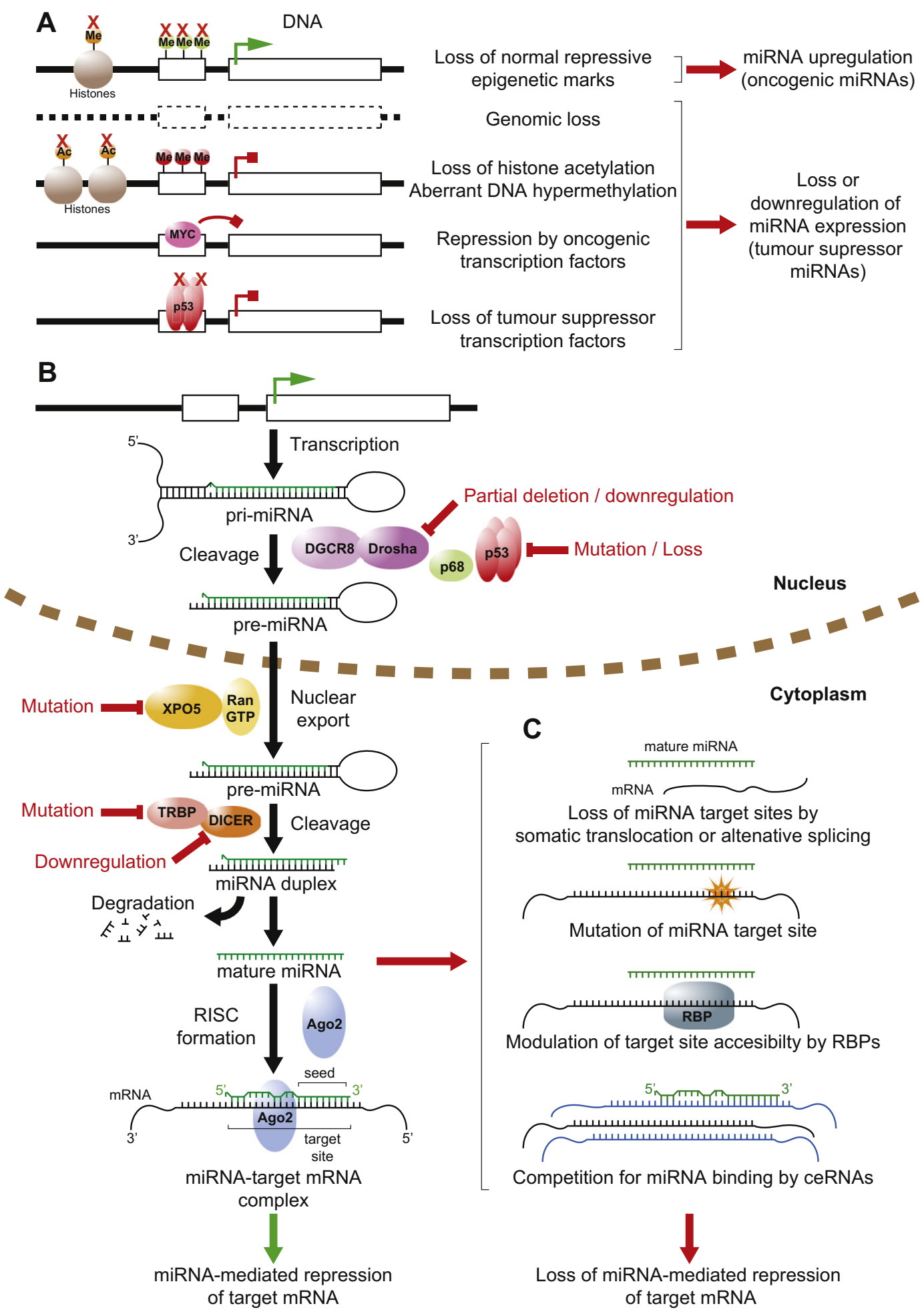

Partial deletion / downregulation
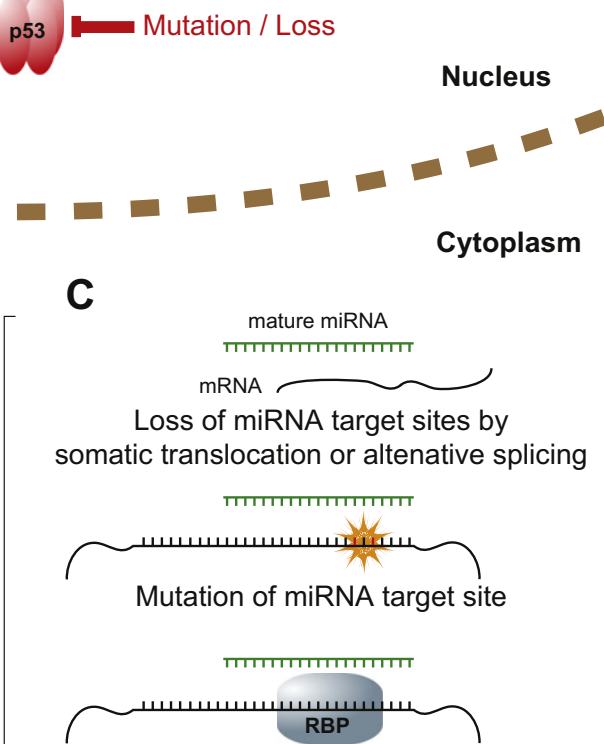

Modulation of target site accesibilty by RBPs

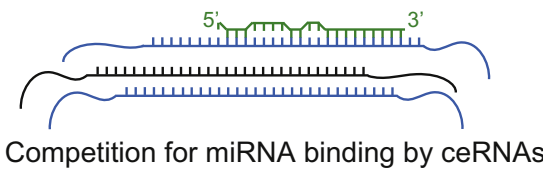

Competition for miRNA binding by ceRNAs

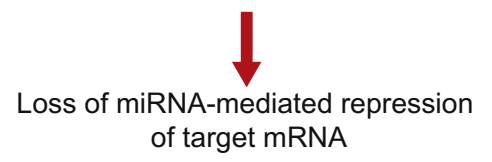

Figure 1 - miRNA deregulation in cancer. A schematic representation depicting the canonical miRNA biogenesis pathway and the general mechanisms whereby normal miRNA expression and function can be deregulated in cancer. $(A)$ Deregulation of miRNA gene transcription in cancer through genetic, epigenetic and transcriptional mechanisms. Active transcription is indicated by green arrow, blocked transcription by red block arrow. Red crosses indicate loss of gene, epigenetic mechanism or transcription factor. Me, methylation; Ac, acetylation. [Refer to Sections 3.1-3.3 in main text.] (B) Simplified canonical pathway of miRNA biogenesis and processing. Steps commonly deregulated in cancer indicated in red. [Sections 1 and 3.4] $(C)$ Mechanisms prevalent in cancer allowing mRNAs to escape regulation by miRNAs. RNA binding protein abbreviated as RBP. ceRNAs represented in blue. [Section 3.5]. 
Wightman et al., 1993), it was not before their characterization in several species in 2001 (Lagos-Quintana et al., 2001; Lau et al., 2001; Lee and Ambros, 2001) that the importance of miRNA in normal physiology and pathology began to emerge. Microarray expression data from a wide spectrum of cancer diseases have since evidenced that aberrant miRNA expression is the rule rather than the exception in cancer (Croce, 2009; Lu et al., 2005; Munker and Calin, 2011; Volinia et al., 2006). Importantly, mouse models featuring miRNA overexpression or ablation have demonstrated causal links between miRNAs and cancer development and miRNAs are rapidly entering the clinic as biomarkers and putative therapeutic targets (Iorio and Croce, 2012; Kasinski and Slack, 2011).

In normal physiology miRNAs are integral parts of feedback circuits and via their buffering effects confer robustness to key biological processes. As such, miRNA may serve to increase the precision of gene expression by dampening the production of proteins being expressed outside their physiologically optimal boundaries (Herranz and Cohen, 2010; Hornstein and Shomron, 2006; Levine et al., 2007). In addition, individual miRNAs may serve as switches in a particular differentiation pathway as exemplified by early studies in worms, such as the regulation of lin-41 by let-7 (Reinhart et al., 2000). Similar roles have been recapitulated in many mammalian differentiation pathways, as for instance exemplified by the regulation of skin differentiation by miR-203 (Yi et al., 2008) or smooth muscle cells by miR-143/145 (Cordes et al., 2009). The ability of even a single miRNA to influence cell identity was further corroborated in early overexpression studies showing that transfecting HeLa cells with a single miRNA, miR-124, shifted the expression profile towards that found in the brain, a tissue in which miR-124 is highly expressed (Lim et al., 2005). From their role in differentiation, formation of cellular identity and their noise-dampening effect, it follows that loss of miRNA function may result in increased cellular plasticity, de-differentiation and a higher propensity for oncogenic transformation (Herranz and Cohen, 2010; Hornstein and Shomron, 2006; Kumar et al., 2007; Peter, 2009).

Interestingly, miRNA also play key roles in stem cells and stem cell differentiation (Heinrich and Dimmeler, 2012) and in induced pluripotency where a single miRNA cluster, miR302 , was recently shown to be able to produce iPSC from both human and mouse fibroblasts (Anokye-Danso et al., 2011).

The tight integration of miRNAs in cellular regulatory circuits may also constitute an Achilles heel, where deregulation of a small subset of miRNA may profoundly affect the expression pattern and drive cells towards transformation (Sotiropoulou et al., 2009). Currently, more than 1400 human miRNAs have been identified many of which are strongly conserved even among distantly related vertebrates and invertebrates (Griffiths-Jones, 2010). Overall, the potential for miRNAmediated regulation of gene expression is enormous as more than $60 \%$ of all mRNAs are predicted to be under miRNA control (Bartel, 2009). Hence, miRNA regulation appears to be the most abundant mode of posttranscriptional regulation.

The literature on miRNAs and cancer is enormous (>7000 PubMed hits as of August 2012) and very diverse both in terms of the diseases in study and the experimental approaches taken. However, a returning challenge in studying miRNAs is the considerable level of redundancy (Alvarez-Saavedra and
Horvitz, 2010). Firstly, as a particular miRNA targets a host of mRNAs, the phenotypic outcome of deregulating even individual miRNAs is unlikely to be mediated via a single target. Although the overwhelming majority of published papers focus on individual targets, most miRNAs like exert their full functional effects via multiple target mRNAs, some of which may reside in the same cellular pathway. Secondly, many miRNAs exist in families with similar seed sequences, which complicates the interpretation of many experimental settings. Lastly, redundancy also exists at the level of the target mRNAs where different miRNAs with distinct seed sequences may corepress the same target (Tsang et al., 2010). Studying miRNA links to cancer is furthermore complicated by the genetic diversity of tumours and cancer cell lines and by that fact that most often many miRNAs are found deregulated in the same tumour. Furthermore, due to the many transcripts regulated by individual miRNAs, their overall function in oncogenesis may be context dependent. Accordingly, a particular miRNA may be found upregulated in some cancer types, and thus supposedly oncogenic, but downregulated in other cancers, indicative of tumour suppressor function. Examples include miR-29 that appears to act as a tumour-suppressor in lung tumours whereas in breast cancer this miRNA may have oncogenic functions (Fabbri et al., 2007; Gebeshuber et al., 2009). Likewise, miR-26a is downregulated in hepatocellular carcinoma where its reintroduction induces apoptosis (Kota et al., 2009). However, the gene is amplified in gliomas (Huse et al., 2009) and overexpression of miR-26a promotes a metastatic phenotype in lung cancer cells (Liu et al., 2012).

Hence, one should be careful in drawing firm conclusions before a particular function or phenotype has been reproduced genetically in a suitable model system.

\section{2. miRNAs are generally downregulated in cancer}

While the deregulation of miRNAs is well documented in a range of diseases, direct causal links have only recently been elucidated. Pivotal for this has been the development and analyses of mouse strains overexpressing or lacking individual miRNAs or miRNA clusters. In addition, characterizations of Dicer knockout strains have investigated the importance of the miRNA regulatory system as such in both normal physiology and cancerous diseases.

Tumours often present reduced levels of mature miRNAs (Lu et al., 2005) as a consequence of genetic loss, epigenetic silencing, defects in their biogenesis pathway or widespread transcriptional repression as documented for MYC (Chang et al., 2008) (Figure 1A). Reduced DICER expression levels have been found in human tumours (Karube et al., 2005; Melo et al., 2009; Pampalakis et al., 2010; Zhu et al., 2012) and, in addition, frame-shift mutations resulting from microsatellite instability have been reported in TARBP2, a DICER stabilizing protein, in colorectal and gastric cancer (Melo et al., 2009), although the frequency of these mutations remains to be established (Garre et al., 2010) (Figure 1B). In contrast to these findings, amplification of the Drosha locus has been reported in oesophageal cancer (Muralidhar et al., 2007) and overexpression of DICER was found to correlate with disease progression in prostate cancer (Chiosea et al., 2006). 


\subsection{Lessons from mouse models}

Although the variable expression pattern of DICER in human tumours indicates a complex and likely cell type-specific dependency of the miRNA biogenesis system in cancer development, the overall picture that emerges from knockout mouse strains is that Dicer is a haploinsufficient tumour suppressor (Kumar et al., 2009). Interestingly, DICER loss-of-function mutations or complete genomic loss have not been reported from human tumours, indicating that a certain minimum level of DICER is needed for tumorigenesis or cell survival. The existence of Dicer knockout cell lines, such as embryonic stem cells (Kanellopoulou et al., 2005), indicates that the phenomenon may be cancer-specific. This is corroborated by genetic evidence showing that mono-allelic, but not bi-allelic, Dicer loss promotes the formation of retinoblastomas in compound mice lacking also pRb and p107 (Lambertz et al., 2010). Interestingly, it was later shown that show that Dicer1 deficiency is tolerated only in pRb-deficient retinal progenitor cells harbouring an intact p53 pathway suggestive of synthetic lethality (Nittner et al., 2012).

miR-155 has been found overexpressed in many cancer types including hematopoietic cancers, breast, lung and colon cancer (Faraoni et al., 2009). miR-155 was the first miRNA studied in a mouse model and in accordance with activation of the Bic locus (encoding miR-155) in retroviral insertional mutagenesis screens (Tam and Dahlberg, 2006), overexpression of miR155 in early B-cells results in pre-leukemic expansion of the pre-B-cell population ultimately resulting in full-blown B cell tumours (Costinean et al., 2006). Interestingly, miR-155 is also linked to key cancer pathways as the gene is upregulated by mutant $\mathrm{p} 53$ in breast tumours facilitating tumour cell invasion (Neilsen et al., in press). Because of its widespread overexpression in cancer miR-155 has attracted considerable interest as a putative therapeutic target (Babar et al., 2012).

miR-21 was the first miRNA to be coined an oncomiR due to the rather universal overexpression of this miRNA in cancer (Volinia et al., 2006). Mechanistically, this has been explained through the identification of key downstream target genes, such as PTEN, PDCD4 and SPRY1 (Frankel et al., 2008; Meng et al., 2007; Thum et al., 2008). Studies in miR-21 knockout mice have demonstrated reduced lung tumour burden following activation of a mutant Kras ${ }^{\mathrm{G} 12 \mathrm{D}}$ allele and, in accordance, a miR-21 transgene resulted in increased tumour outgrowth (Hatley et al., 2010). In a separate transgenic line, inducible miR-21 overexpression resulted in potent lymphoma development adding direct proof to the concept of miR-21 as a bone fide oncogene (Medina et al., 2010). This study furthermore established that tumours become addicted to miR-21 overexpression as transcriptional shut off of the transgene resulted in rapid tumour regression likely due to apoptosis. Hence, miR-21 inhibition appears a promising therapeutic strategy.

The polycistronic miR-17-92 cluster encodes 6 different miRNAs and mammals encode in addition two paralog clusters, the miR-106a-363 and the miR-106b-25 clusters (Concepcion et al., 2012a). The miR-17-92 cluster is located at a fragile site in the genome (Calin et al., 2004) and has been found amplified in several tumour types (Castellano et al., 2009; He et al., 2005). In accordance with this, the cluster has been found overexpressed in many cancers include lung, colon and gastric cancer (Concepcion et al., 2012a). The miR17-92 locus is additionally linked to cancer-related pathways in that the cluster is regulated by both MYC and E2F family members (O'Donnell et al., 2005; Woods et al., 2007).

Transgenic mice overexpressing miR-17-92 developed lymphoproliferative disorders (Xiao et al., 2008) and retroviral overexpression of the cluster accelerated lymphoma formation in collaboration with MYC (He et al., 2005). Two groups have independently dissected the cluster using knockout mice and demonstrated that loss of miR-17-92 leads to reduced tumourgenicity and increased cell death $(\mathrm{Mu}$ et al., 2009; Olive et al., 2009). Interestingly, the miR-19 seed family was identified as the main pro-survival effector in part via repression of the Pten tumour suppressor (Mu et al., 2009; Olive et al., 2009).

The miR-34 family consists of three highly related miRNAs, miR-34a, miR-34b and miR-34c, respectively. In addition, miR449 carries the same seed sequence and has been found to regulate many of the same target genes as miR-34 family members (Bou Kheir et al., 2011; Lize et al., 2010). Several groups have reported miR-34 members as important downstream effectors of the p53 tumour suppressor and canonical p53 target sites are present in the miR-34 promoters (Figure 2) (Chang et al., 2007; He et al., 2007a; Raver-Shapira et al., 2007). In accordance with a tumour-suppressive role, miR-34 members are downregulated in various cancers and the miR-34a locus located at 1q36 has been found lost in cases of neuroblastomas and in pancreatic cancer cell lines (Chang et al., 2007; Welch et al., 2007). Corroborating this, epigenetic silencing of miR-34 family members has been documented (Corney et al., 2010; Gallardo et al., 2009). Oncogenic functions have been ascribed to their many target genes involved in growth control, including Cyclin E2, MYC, MET, BCL2, SIRT1 and E2F family members (Bommer et al., 2007; Christoffersen et al., 2009; Corney et al., 2007; Hermeking, 2012; Tazawa et al., 2007; Yamakuchi et al., 2008).

Surprisingly, mice harbouring the combined loss of all three miR-34 members are viable and fertile, do not display morphological defects and are not prone to spontaneous tumour formation (Concepcion et al., 2012b). Furthermore, the p53 response was found to be normal in DNA-damage assays, during senescence and following oncogene activation. These findings are difficult to reconcile with reports placing miR-34 downstream p53 and illustrate the importance of genetic studies in understanding the significance of miRNA. Whereas Conception et al studied three arms of the p53 pathway, functions in other downstream processes such as autophagy and quiescence remain to be analysed. In addition, genetic redundancy with the closely related miR-449 family may obscure the effects.

\section{Mechanisms for miRNA deregulation and escape from miRNA-mediated repression}

Over the past decade, the degree to which miRNAs are involved in cancer has really become apparent. As has the sheer diversity of mechanisms by which miRNA function is deregulated, the major general causes of altered miRNA expression in cancer are discussed below and summarised in Figure 1. 


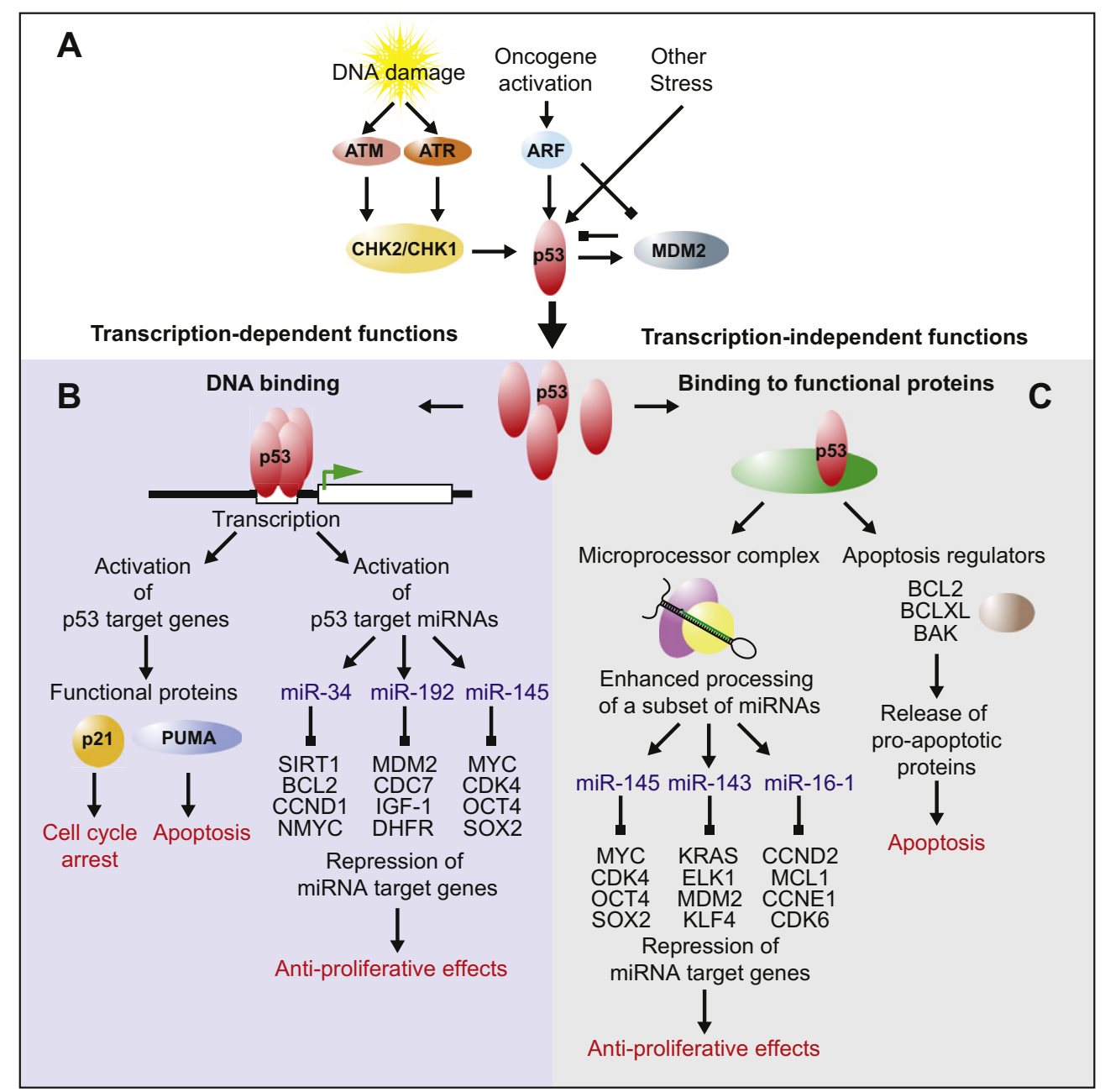

Figure 2 - Functions of $\mathrm{p} 53$. This diagram depicts the activation and functions of the p53 tumour suppressor and their cellular effects. $(A)$ Key proteins participating in the activation and posttranscriptional control of p53 in response to cellular stress are shown. [Refer to Section 4.3 in main text.] (B) Functions of $\mathrm{p} 53$ dependant on its role as a transcription factor are summarised here. Representative examples of p53 activated proteins and miRNAs are shown, as are a selection of targets for each miRNA. [Sections 3.3.2, 4.3.3] $(C)$ Transcription-independent functions of p53 relying on its participation in protein-protein interactions. Examples of miRNAs upregulated post-transcriptionally by $\mathrm{p} 53$ and a selection of their target genes are shown. Examples of apoptotic regulators bound by p53 are shown. [Sections 3.3.2, 4.3.3].

\subsection{Genetic alterations}

In 2004 it was reported that around 50\% of miRNAs are located at fragile sites and cancer susceptibility loci (Calin et al., 2004). However since then, many more miRNAs have been identified and the relationship between site fragility and miRNA density seems far more complex than previously thought.

More complete mapping of the human miRNA genes on fragile sites, cancer-specific translocation breakpoints, repetitive sequences and CpG islands has since been conducted and reveals that miRNA genes are indeed associated with fragile sites (Lagana et al., 2010). However the same is true for protein coding genes and indeed no significant difference between miRNAs and genes in terms of their distribution in fragile versus non-fragile sites was apparent. Significant differences in distribution between miRNAs and genes arose when specific chromosomes were analysed. For example, a far higher incidence of miRNAs in fragile sites compared to that of genes was observed in chromosome 19, although in chromosome 14 the reverse is true.

These studies however are more general, the relationship between cancer-related regions and miRNA locations is not straight-forward and probably cancer type specific (Lamy et al., 2006).

Aside from structural genetic changes, somatic translocations of miRNA target sites have also been documented resulting in escape from regulation of an mRNA target by a specific miRNA (Mayr et al., 2007).

Potentially, mutations that alter an miRNA seed sequence could ablate target repression by tumour-suppressive miRNAs or allow for altered target selection, which could contribute to oncogenesis. Whereas naturally occurring sequence variations, such as SNPs, have been shown to influence miRNA targeting in cancer-related pathways (Mishra et al., 2008; Wynendaele et al., 2010), tumour-specific mutations seem to be infrequent. Sequencing from cancer cells has indicated 
that despite mutations being detected in miRNA primary transcripts there was no evidence of mutations that altered the sequence of the mature miRNA (Diederichs and Haber, 2006). Although the possibility exists for mutations in the primary transcripts to alter the secondary structure and hence affect the processing of miRNA precursors, this did not appear to be the case.

\subsection{Epigenetic mechanisms}

Aberrant epigenetic changes are a well-known feature of cancer cells, such as DNA hypermethylation of tumour suppressor genes, extensive genomic DNA hypomethylation and alteration of histone modification patterns (Lopez-Serra and Esteller, 2012).

In a similar fashion to protein coding genes, miRNA genes are also subject to epigenetic changes in cancer. A large proportion of miRNA loci are associated with CpG islands giving strong basis to their regulation by DNA methylation (Weber et al., 2007). The majority of studies have used treatment with chromatin remodelling drugs to reveal epigenetically silenced miRNAs.

For example, upregulation of hypermethylated tumour suppressing miRNAs by 5-aza-2'deoxycytidine treatment in the case of as miR-127 (Saito et al., 2006), miR-9-1 (Lehmann et al., 2008) and the miR-34b/c cluster (Toyota et al., 2008). Similarly differential miR-124a expression was observed in miRNA profiles from colorectal cancer cells deficient in DNMT1- and DNMT3b-enzymes (Lujambio et al., 2007). On the other hand, potentially oncogenic miRNAs can be upregulated by DNA hypomethylation (Brueckner et al., 2007; Iorio et al., 2007).

Specific transcription factors can recruit chromatin remodelling enzymes to individual miRNA loci, as seen in the case of miR-223 silencing by the AML1/ETO, the most common fusion protein associated with acute myeloid leukaemia (Fazi et al., 2007). Here either siRNA treatment against AML1/ETO or demethylating treatment enhanced miR-223 levels and restored cell differentiation (Fazi et al., 2007).

Mapping-based approaches have also helped identify miRNA promoters silenced in cancers. One study looked for associations between DNA methylation status of promoters of cancer-associated miRNAs and miRNA expression in breast cancer cells (Wee et al., 2012). A previously unknown alternative promoter of the miR-200b cluster was identified. Moreover, differential methylation patterns of this and the known promoter were observed in different breast cancer sub-types (Wee et al., 2012).

As well as DNA methylation, histone acetylation represents another epigenetic phenomenon deregulated in cancer. Reduction in the level of acetylated histones can diminish expression of anti-oncogenic miRNAs as evident from studies utilising histone deacetylase inhibitors where alteration of miRNA levels were observed following treatment (Saito et al., 2006; Scott et al., 2006).

The relationship between miRNAs and epigenetics is deepened by the fact that certain miRNAs have been reported to regulate components of the epigenetic machinery. Expression of miR-29, for example, can inhibit DNMT3A and DNMT3B expression (Fabbri et al., 2007), thus counteracting aberrant DNA methylation. Restoration of miR-29 expression in non-small- cell lung cancer cells led to de-repression of tumour suppressor genes silenced by CpG island methylation (Fabbri et al., 2007). In addition, miR-101 targets the histone methyltransferase EZH2, which contributes to the epigenetic silencing of target genes and regulates the survival and metastasis of cancer cells (Varambally et al., 2008). In prostate cancer miR-101 expression decreases during cancer progression, parallelling an increase in EZH2 expression (Varambally et al., 2008). SUZ12, another component of the polycomb repressor complex 2 (PRC2), of which EZH2 is the catalytic subunit, is targeted by the miR-200 family (Iliopoulos et al., 2010). This appears to be important in the formation of cancer stem cells where loss of miR-200 increases SUZ12 expression, SUZ12 binding, H3-K27 trimethylation, and Polycomb-mediated repression of the E-cadherin gene (Iliopoulos et al., 2010).

\subsection{Regulation of miRNAs by transcription factors in cancer}

Aside from genetic and epigenetic influences, deregulation of miRNA expression can result from aberrant transcription factor activity in cancer cells.

Nearly half of miRNA genes are located in the introns of protein coding or long non-coding RNA genes while the rest are distinct transcriptional units with their own promoters (Kim et al., 2009b) and are transcribed by RNA polymerase II (Lee et al., 2004). miRNA genes are often clustered and transcribed as polycistronic messages or excised from mRNAs. A plethora of Pol-II associated transcription factors are responsible for control of miRNA genes, with a single factor potentially able to activate or repress numerous miRNA genes. Intriguingly, transcription factors are often targets for repression by the miRNAs they regulate, generating complex feedback and feed-forward circuits.

3.3.1. miRNA suppression by oncogenic transcription factors The oncogenic transcription factor Myc binds promoter regions of many miRNAs. Although Myc is responsible for upregulating the oncogenic miR-17-92 cluster (Dews et al., 2006), the principal effect of Myc activation is widespread repression of miRNA expression (Chang et al., 2008). Among those miRNAs downregulated by Myc are several with documented antiproliferative, pro-apoptotic and tumour suppressor effects, such as let-7, miR-15a/16-1, miR-26a and miR-34 family members (Bui and Mendell, 2010). Transcriptional functions of Myc can also indirectly lead to miRNA repression, for example LIN28A and LIN28B are activated by Myc and are required for repression of the let-7 miRNA (Chang et al., 2009), itself a negative regulator of Myc (Kim et al., 2009a).

Several studies have demonstrated a role of miRNAs in other transcription factor networks in cancer, like that of the activated Ras oncogene. Ras activation leads to repression of the miR-143/145 cluster in KRAS mutant pancreatic cancers through Ras-responsive element-binding protein (RREB1) binding to the miR-143/145 promoter (Kent et al., 2010). Furthermore, KRAS and RREB1 are themselves targets of miR143/miR-145, representing a feed-forward loop that further amplifies Ras signalling (Kent et al., 2010).

Likewise, the transcriptional repressor ZEB1 directly inhibits transcription of microRNA-200 family members miR- 
141 and miR-200c, which in turn regulate both ZEB1 and ZEB2 (Bracken et al., 2008; Christoffersen et al., 2007), and strongly activate epithelial differentiation in pancreatic, colorectal and breast cancer cells (Burk et al., 2008).

\subsection{2. miRNA downregulation by loss of tumour suppressor transcription factors}

Transcription of miRNAs with anti-tumorigenic effects is of ten activated by transcription factors that are themselves tumour suppressors. Since many tumour suppressors are lost or mutated in cancer this can also result in loss of expression of miRNAs with important growth suppressive roles.

The well-known transcription factor p53 governs the cellular response to DNA damage and plays a crucial role in regulation of the cell cycle and apoptosis (Figure 2). Its importance is emphasised by the fact that it is mutated in $50 \%$ of human cancers and its function is deregulated by various other mechanisms in a large proportion of the remainder. Several miRNAs are under transcriptional control of p53 (Figure 2B,C). Profiling of miRNA expression levels after induction of $\mathrm{p} 53$ by genotoxic stress has indicated the miR-34 family members - $a,-b$ and -c as the most strongly up-regulated miRNAs, with transcription of pri-miRNAs from both the miR-34a and miR-34b/c loci activated in a p53-dependent manner (Chang et al., 2007; He et al., 2007a; Tarasov et al., 2007). The mRNA targets of the miR-34 family include cyclins D and E2, cyclin-dependent kinases 4 and 6 (CDK4 and CDK6), CDC25c, Myc and BCL2 (Hermeking, 2012). Given the functions of these various target genes in promoting cell proliferation and inhibiting cell cycle arrest and apoptosis, it is plain that miR-34 induction by $\mathrm{p} 53$ complements its role in the negative regulation of cell growth (Chang et al., 2007; Hermeking, 2009, 2012; Raver-Shapira et al., 2007; Tazawa et al., 2007).

Several other miRNAs have also been described as transcriptional targets for p53. For example miR-107, miR-200 or miR-192, which are miRNAs that inhibit angiogenesis and epithelial-to-mesenchymal transition (Chang et al., 2011; Yamakuchi et al., 2010). Furthermore a number of p53activated miRNAs including miR-192, miR-194, miR-215, miR-605 and miR-143/145, have been shown to target MDM2 (Figure 3) (Pichiorri et al., 2010; Xiao et al., 2011; Zhang et al., in press). Itself a p53 target gene, MDM2 is the principal negative regulator of p53 (Manfredi, 2010), thus activation of these afore mentioned miRNAs introduce additional regulatory complexity into the p53-MDM2 feedback loop.

The role of p53 in activating the transcription of multiple miRNAs bolsters its tumour suppressor function (Figure 2B) and the mutation or deregulation of p53 in cancers can result in loss of expression of miRNAs (Figure 1A), further exacerbating cellular transformation, tumour formation and spread.

Also of note, the p53 family member p63 positively regulates transcription of Dicer1 (as well as miR-130b) (Su et al., 2010). Tumours deficient in p63 have extremely low Dicer1 expression, resulting in lower levels of mature miRNAs and an increased propensity for metastasis (Su et al., 2010). Although mutations in $\mathrm{p} 63$ appear to be a rare event in cancer, it is lost in a variety of tumour types and this often correlates with invasive capability (Muller et al., 2011).

\subsection{Mutations in miRNA biogenesis pathways}

The expression level of miRNA can also be modified as a result of defects in the miRNA biogenesis pathway (see Figure 1B). Deregulation of enzymes and cofactors involved in these pathways can affect the levels of mature miRNAs and have important biological ramifications.

Central evidence for this has come from in vivo studies in which Drosha and Dicer1, two key enzymes in miRNA processing, have been disrupted and led to the conclusions that these proteins function as haploinsufficient tumour suppressors as also discussed above. Partial deletion of Dicer1 and Drosha has been shown to hasten tumorigenesis in vitro and

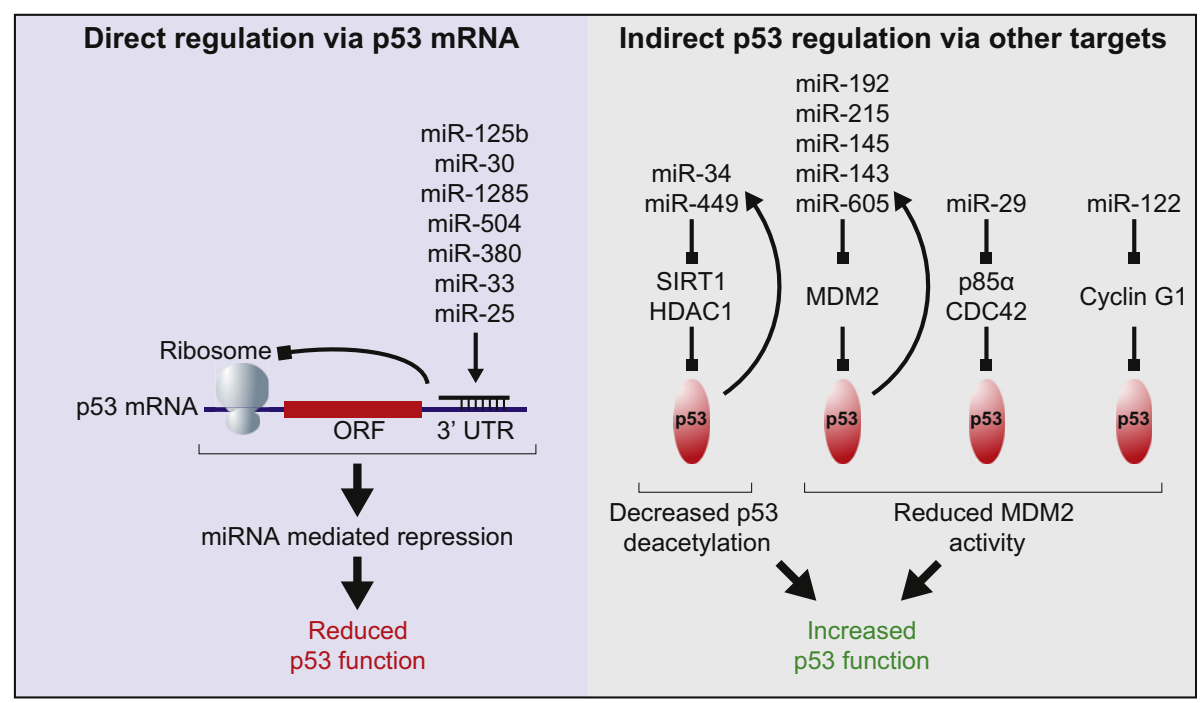

Figure 3 - Regulation of p53 by miRNAs. Left: miRNAs directly repressing p53 through binding to sites in the p53 3'UTR. Right: Examples of miRNAs positively regulating $\mathrm{p} 53$ through repression of a selection of other targets that antagonise $\mathrm{p} 53$ function. Block arrows indicate repression. Feedback loops where p53 is also capable of increasing the miRNA levels are indicated with arced arrows. [Refer to Sections 3.3.2, 4.3.1, 4.3.3 in main text]. 
in vivo (Kumar et al., 2007). In lung epithelia, conditional deletion of one Dicer1 allele accelerates growth of lung adenocarcinomas in a KRAS mouse model, while knockout of both alleles inhibits their formation (Kumar et al., 2009). Also, there was selection against full loss of Dicer1 expression in the tumours (Kumar et al., 2009). Furthermore, although analysis of human cancer genome copy number data revealed frequent deletion of Dicer1, the gene has not been found to undergo homozygous deletion (Kumar et al., 2009).

In a similar way, other factors involved in miRNA processing have also been described as haploinsufficient tumour suppressors. For example, mutations of TARBP2 that impair miRNA processing and mutations of XPO5 that trap miRNA transcripts in the nucleus correlate with carcinomas characterised by microsatellite instability (Melo et al., 2009, 2010). Several other proteins also play important roles in miRNA processing including the DEAD-box helicases p68 (DDX5) and p72 (DDX17) as well as members of the SMAD protein family. It is likely that the normal functions of these proteins in miRNA biogenesis are also subverted in cancer (Davis et al., 2008; Newman and Hammond, 2010; Warner et al., 2004).

Certain miRNAs and families appear to have more specific factors that regulate their biogenesis. The processing of the let-7 microRNA, for example, is modulated by Lin28, a highly conserved RNA-binding protein, with important consequences for cell pluripotency, developmental timing and oncogenesis (Viswanathan and Daley, 2010).

The tumour suppressor p53, as mentioned above, is a key regulator of miRNAs with anti-oncogenic roles. In addition to its capacity to modulate miRNA expression levels through its function as a transcription factor, it also exerts an influence on miRNA biogenesis in a transcription-independent manner. As discussed further below, p53 has been described to modulate miRNA processing through interaction with the Drosha processing complex (Suzuki et al., 2009).

Interestingly, there are indications that miRNA processing can also be regulated by other miRNAs. The miR-103/107 family has been shown to target Dicer thereby reducing global miRNA levels (Martello et al., 2010). Elevated levels of miR$103 / 107$ are seen in aggressive breast cancers and correlates with increased metastatic potential. Mechanistically this is thought to occur by induction of epithelial-to-mesenchymal transition (EMT) through downregulation of miR-200 levels (Martello et al., 2010).

\subsection{Mechanisms for escape from repression by miRNAs}

\subsubsection{Mutations in miRNA target sites}

During carcinogenesis, point mutations can alter the function of protein coding genes resulting, for example, in activated oncogenes or deactivated tumour suppressors. As mentioned above, this type of mechanism, being mutation of the seed sequence in the case of mature miRNAs, appears rare.

However, sequence variation in the miRNA target sites present in the mRNA seemingly does occur allowing mRNAs to avoid binding and consequent negative regulation by $\mathrm{miR}-$ NAs (Figure 1C). Indeed, there is evidence that this mechanism plays a role in tumorigenesis. Bioinformatic analysis of expressed sequence tag and single nucleotide polymorphism
(SNP) databases has demonstrated differing allele frequencies of miRNA-binding sites in cancers compared to normal tissues (Yu et al., 2007). Specific incidences of this have been demonstrated experimentally, such as the case of let-7 and its oncogenic target HMGA2. In several tumours, the open reading frame and the 3'UTR that contains let-7 target sites have been found separated by chromosomal rearrangements at the HMGA2 locus resulting in escape of HMGA2 from let-7 regulation, overexpression of the protein and promotion of tumour formation (Lee and Dutta, 2007; Mayr et al., 2007). In another example observed in non-small cell lung cancer, also involving let-7, a SNP in the let-7 target site in the $3^{\prime} \mathrm{UTR}$ of the KRAS oncogene allows elevated KRAS expression and correlates with increased cancer risk (Chin et al., 2008).

\subsubsection{Alternative splicing or polyadenylation}

Alternative splicing or polyadenylation site usage represent other mechanisms that can generate alternative $3^{\prime}$ UTRs in mRNAs, altering the occurrence of miRNA target sites (Figure 1C). One study has described the role of miR-9 and $\mathrm{miR}-125 \mathrm{a} / \mathrm{b}$ in neuronal cells, where they act in concert to regulate cell proliferation by repressing only the truncated isoform of the neurotrophin receptor tropomyosin-related kinase $C$ and not the full length isoform, which lacks the miRNA binding sites (Laneve et al., 2007). In neuroblastoma these three miRNAs are under-expressed, allowing aberrant proliferation.

Furthermore, an increased proliferation state may be associated with widespread reductions in the $3^{\prime} \mathrm{UTR}$-based regulatory capacity of mRNAs. It has been shown that one characteristic of gene expression during immune cell activation is that the proliferating cells express mRNAs with shortened 3'UTRs and that this increases the protein expression from such mRNAs (Sandberg et al., 2008). This may also be a feature in proliferating cancer cells as a comparison of multiple cancer cell lines and similarly proliferating nontransformed cell lines revealed that a small but significant number of mRNA isoforms with shorter 3'UTRs were present in the cancer cells (Mayr and Bartel, 2009). It was found that these isoforms typically resulted from alternative cleavage and polyadenylation with the shorter mRNA isoforms exhibiting increased stability and typically producing ten-fold more protein, partly through the loss of microRNA-mediated repression (Mayr and Bartel, 2009). Functionally, the truncated isoform of the proto-oncogene IGF2BP1 was shown to increase the frequency of oncogenic transformation more than expression of the full-length isoform (Mayr and Bartel, 2009).

\subsubsection{Target site exclusion on mRNA}

Accessibility of miRNA binding sites can also be regulated by the secondary structure of the mRNA molecule, which can be modulated through association of RNA binding proteins (Figure 1C). Interestingly, sometimes sequences in the vicinity of a miRNA target site are highly evolutionarily conserved. This led to the hypothesis that these sequences represent docking platforms for RNA binding proteins to act as modulators of miRNA activity. The first RNA binding factor to be identified with such a function was dead end 1 (Dnd1) (Kedde et al., 2007). This conserved protein acts to prohibit several miRNAs from associating with their targets via binding to uridine-rich 
regions present in certain mRNAs (Kedde et al., 2007). Furthermore, Dnd1 may have some importance in cancers as it protects the LATS2 tumour suppressor from inhibition by the miR-372 family and also for its role in germ-cell survival and perhaps tumour formation, although these findings await further clarification (Kedde et al., 2007). The same group also identified the ubiquitously expressed Pumilio (PUM1) as another RNA binding protein regulating miRNA target site accessibility (Kedde et al., 2010). They demonstrated that PUM1 binding to the mRNA of the p27 tumour suppressor induces a local change in RNA structure that favours association with miR-221 and miR-222, leading to suppression of p27 expression and rapid cell cycle progression (Kedde et al., 2010). Elevated levels of miR-221 and miR-222 are required in various cancers to inhibit the expression of p27 and stimulate cell proliferation (le Sage et al., 2007) and PUM1 is also mutated in some cancers (COSMIC database, Wellcome Trust Sanger Institute) where it may facilitate this negative regulation of p27.

Given that many of these conserved sequence regions exist in proximity to miRNA binding sites, it is likely that future research will uncover many more RNA binding proteins that regulate miRNA targeting, and that a proportion of these will be deregulated in cancer.

\subsubsection{Competition for miRNA binding by other endogenous} RNAs

The emergence of other functional non-coding RNAs (ncRNA) has hinted at the possible complexity of the RNA-ome as a network of inter-communicating regulatory molecules.

An early study reporting the existence of a connection between other ncRNAs and miRNAs involved in cancer observed that a significant proportion of ultraconserved genomic regions code for specific set of ncRNAs whose expression is perturbed in human cancers and also regulated by aberrantly expressed miRNAs (Calin et al., 2007). The idea of some miRNA target mRNAs acting as "pseudotargets" was proposed in an attempt to resolve several paradoxical observations surrounding the number of computationally predicted target sites, degree of conservation across species and the fairly low extent of miRNA mediated repression on target mRNAs (Seitz, 2009). Subsequently, the Competing Endogenous RNA (ceRNA) hypothesis was introduced, proposing that endogenous RNAs, for example protein coding and non-coding transcripts containing common miRNA recognition elements (MREs), can compete for the binding of a limited pool of miRNAs thereby co-regulating one another (Figure 1C) (Salmena et al., 2011). This hypothesis is exemplified experimentally by work on the tumour suppressor PTEN mRNA, where MREs are conserved in its related pseudogene PTENP1 (Poliseno et al., 2010). Overexpression of the PTENP1 3'UTR increased levels of PTEN and resulted in growth inhibition in a DICER-dependent manner. Interestingly, PTENP1 may be a tumour suppressor gene since copy number losses at the PTENP1 locus were found to occur in sporadic colon cancer (Poliseno et al., 2010).

Similar regulation by pseudogenes was observed for other important cancer genes like KRAS and its pseudogene KRAS1P (Poliseno et al., 2010). In addition, a long non-coding RNA (lncRNA) Highly Upregulated In Liver Cancer (HULC) sequesters miR-372 in order to modulate its own transcriptional upregulation in hepatocellular carcinoma (Wang et al., 2010).
As a consequence of these and other studies, more indepth analysis of the role of pseudogenes and lncRNAs in cancer is being carried out since they can potentially act as potent tumour suppressors and oncogenes.

\section{4. miRNA regulation of key cancer-related pathways}

Rather than offer an exhaustive review of all literature on the subject, we here limit ourselves to present concepts and general mechanisms by which miRNAs can contribute to the function and regulation of the cell cycle, cellular senesence and the DNA damage response and the impact of these on cancer biology. We shall omit broader discussion of miRNA functions in the processes of apoptosis and autophagy, which have been covered in recent reviews (Frankel and Lund, in press; Lima et al., 2011).

\subsection{Cell cycle and proliferation control}

The role of miRNAs in the control of cell proliferation is now well established and there exist a great many reports of how they contribute to carcinogenesis by perturbing critical cell cycle regulatory pathways. Oncogenic miRNAs, often overexpressed in cancer, can act to facilitate entry and progression through the cell cycle, while tumour suppressor miRNAs lost in cancers assist in the induction of cell cycle arrest.

Central to cell cycle regulation, the retinoblastoma $(\mathrm{pRb})$ pathway is altered in the vast majority of human cancers (Genovese et al., 2006; Henley and Dick, 2012). pRb is a repressor of the E2F family of transcription factors, which govern transcription of genes required for cell cycle progression (Polager and Ginsberg, 2009). This repression is alleviated by phosphorylation of $\mathrm{pRb}$ by cyclin dependent kinases (CDKs), allowing E2Fs to activate transcription of genes, including cyclins and CDKs, necessary for progression to the next phase of the cell cycle (Henley and Dick, 2012). Active CDK complexes are formed from specific cyclin and kinase partners, for example cyclin D with CDK4/6. CDK activity subsequently triggers progression through sequential phases of the cell cycle (Murray, 2004).

Components of the cell cycle machinery such as the cyclins and cyclin dependent kinases (CDKs) are key targets of growth-suppressing miRNAs. This machinery represents a focal end-point for growth regulatory signalling such as growth promoting mitogenic pathways like the RAS/RAF/MAPK axis as well as growth inhibiting pathways such as the p53 pathway (Kastan and Bartek, 2004; Murray, 2004). This is exemplified from early observations showing that the miR-15a-16-1 cluster is lost in multiple cancer types and prompted further investigation into the targets of this miRNA family (Calin et al., 2002). Important positive regulators of the cell cycle, such as CDK1, CDK2 and CDK6 as well as cyclins D1, D3 and E1, number among the validated targets enabling these miRNAs to assist in G1 arrest (Linsley et al., 2007; Liu et al., 2008). Indeed, these and other promoters of the cell cycle, such as positive regulators of CDK activity like the cyclins (He et al., 2007a; Yu et al., 2008) and cell division cycle phosphatases like CDC25A (Sarkar et al., 2010; Yang et al., 2009) are also targeted by miRNAs to inhibit the cell cycle, with 
reports of these miRNAs being downregulated or lost in tumour cells (Bueno and Malumbres, 2011; Johnson et al., 2007; Yu et al., 2008).

The E2F transcription factors themselves have been described as targets of miRNAs with tumour suppressor functions such as those of miR-17-92 cluster, miR-20a and miR125b (Huang et al., 2011; O'Donnell et al., 2005; Pickering et al., 2008).

On the other hand, the expression of negative regulators of the cell cycle can be repressed by miRNAs. Not unexpectedly, it would be to the advantage of cancer cells to up-regulate expression of these miRNAs. Towards this, pRB and family members p107 and p130 are targets of miRNAs found to be upregulated in certain cancers (Benetti et al., 2008; Volinia et al., 2006).

Negative regulators of CDKs represent an important class of cell cycle inhibitors, which again are subject to extensive miRNA-mediated regulation. Prominent examples come from the Cip/Kip family of CDK inhibitors. Firstly, p21 (Cip1), a canonical target gene of $\mathrm{p} 53$ and a potent inducer of G1 arrest, is targeted directly by miR-106b and miR-17-92 families, which show elevated levels in multiple tumour types (Ivanovska et al., 2008; Kim et al., 2009c). Interestingly, although genes are often computationally predicted to be targeted by tens or even hundreds of miRNAs (Krek et al., 2005; Lewis et al., 2005), few are validated experimentally. In the case of p21 though one study demonstrated, by using a luciferase assay reporter screening approach, that 28 different miRNAs, some of which are known to be up-regulated in cancer, can potentially target the 3'UTR of p21 mRNA (Wu et al., 2010).

Secondly p27 (Kip1), whose expression levels are primarily controlled by various posttranscriptional mechanisms (le Sage et al., 2007), and p57 (Kip2) are also targets for several miRNAs, notably those of the miR221/222 cluster (Kim et al., 2009c; le Sage et al., 2007). This may be of particular importance in glioblastomas and prostate cancers where p27 expression shows an inverse correlation to miR221 and miR222 levels (Galardi et al., 2007; Gillies and Lorimer, 2007; le Sage et al., 2007).

In addition, down-regulation of anti-proliferative miRNAs has been observed in response to growth-promoting signalling pathways. A phosphorylated form of TRBP was previously found associated with the Dicer complex (Chendrimada et al., 2005). The mitogen-activated protein kinase (MAPK) ERK, has been attributed responsible for catalysing this TRBP phosphorylation (Paroo et al., 2009). Levels of the let-7 tumour suppressor miRNA family were repressed following TRBP phosphorylation by ERK, while those of growth promoting miRNAs including miR-17, miR-20a and miR-92a were induced (Paroo et al., 2009).

\subsection{MiRNA regulation of senescence}

Senescence is defined as irreversible exit from the cell cycle and can generally be divided into two subgroups; replicative senescence and stress-induced or premature senescence. Replicative senescence occurs as the cells reach a critical "age" as a result of telomere shortening, while stressinduced senescence can be induced as a result of oxidative stress, oncogene expression or DNA damage signalling
(Kuilman et al., 2010). Importantly, senescence is a barrier to tumorigenesis.

miRNAs have been shown to regulate the pathways involved in senescence, indeed many of the miRNAs negatively regulating cell cycle progression may also play roles in senescence induction. For example, the let-7 target HMGA2 is a repressor of the key inducers of senescence p16 and p19, products of the INK4A locus often mutated in cancers (Lee and Dutta, 2007; Nishino et al., 2008; Sherr, 1996). p16 is a specific inhibitor of CDK4/6 and is also repressed by miR24 , which is down-regulated during replicative senescence (Lal et al., 2008).

Also the p53 regulated miR-34 family members, particularly miR-34a, have been implicated as important senescence regulators through suppression of multiple targets (Kumamoto et al., 2008; Tazawa et al., 2007; Yamakuchi and Lowenstein, 2009). Of particular note, the silent information regulator 1 (SIRT1), a deacetylase and a central regulator of senescence (Brooks and $\mathrm{Gu}, 2009$ ) is a direct target of miR-34a (Yamakuchi et al., 2008; Yamakuchi and Lowenstein, 2009). Furthermore, miR-34a expression and inhibition of SIRT1 forms an intricate feedback mechanism since SIRT1 also deacetylates p53 inhibiting its activity and miR-34a transcription (Langley et al., 2002; Vaziri et al., 2001; Yamakuchi and Lowenstein, 2009). Importantly, miR-34a can also be regulated independently of p53, during oncogene-induced senescence, by ELK1 a member of the ETS family of transcription factors (Christoffersen et al., 2009).

At least four miRNA clusters, let-7a-d, let-7i, mir-15b-16-2, and mir-106b-25 are induced during the G1-S transition by E2F1 and E2F3 upon exit of primary fibroblast cells from quiescence (Bueno et al., 2010). Perhaps surprisingly, these miRNAs actually inhibit E2F-dependent S-phase entry by targeting several E2F target genes and promoters of cell cycle progression (Bueno et al., 2010). Hence, E2F-induced miRNAs limit the cellular consequences of E2F activation and prevent replicative stress. Moreover, since the levels of these miRNAs are not significantly altered following DNA damage, they may rather function to promote senescence.

\section{3. miRNAs in DNA damage responses}

The cell constantly monitors its genetic material for abnormalities. The DNA damage response is initiated upon detection of any DNA lesions or alterations in chromatin structure and transduces the damage signal to many cellular systems, such as the DNA-repair machinery and the cell cycle checkpoints. Damage sensor kinases ATM and ATR followed by CHK1 and CHK2 become activated and phosphorylate a number of protein targets including the p53 tumour suppressor protein to initiate a cellular response (Kastan and Bartek, 2004) (Figure 2A). As various types of DNA lesions can occur, a variety of different repair mechanisms exist. In addition to directly repairing DNA breaks or adducts, cells respond to DNA damage by halting cell-cycle progression or by undergoing apoptosis (Kastan and Bartek, 2004). Thus, the DNA damage response and cell cycle control are critically linked.

There is now a wealth of evidence that miRNAs play an important role in the regulation of the DNA damage response. 
Both transcription and processing of miRNAs is regulated by various factors during DNA damage, in turn miRNAs regulate the DNA damage response via inhibition of their targets. Some important examples of these different facets to miRNAmediated regulation of the DNA damage response and their relevance to cancer will be discussed below.

\subsubsection{Transcriptional regulation of miRNA expression during DNA damage}

miRNA levels can be transcriptionally modulated during the DNA damage response by transcription factors in a similar fashion to protein coding genes. The first report connecting p53 to regulation of miRNAs identified the miR-34 family as direct transcriptional targets of p53 (He et al., 2007a; RaverShapira et al., 2007). There exist many targets of the miR-34 family that contribute to its anti-proliferative functions, including negative regulators of the cell cycle and apoptosis as discussed above (Chang et al., 2007). The miR-34 family and its variety of functions has become an intensely studied area with a large number of publications relating to this important tumour suppressor miRNA family (He et al., 2007b; Hermeking, 2009).

The critical negative regulatory partner of $\mathrm{p} 53$, MDM2 protein, is an oncogene in its own right and often amplified in cancers (Wade et al., 2010). MDM2 participates in a negative feedback loop with p53 where its expression is induced by p53 and it is then able to target p53 for degradation thus keeping p53 levels low. Under conditions of cellular stress the ability of MDM2 to negatively regulate p53 is ablated, in part by phosphorylation of MDM2 by the DNA damage kinases, allowing accumulation of $\mathrm{p} 53$ protein and activation of its antiproliferative program (Wade et al., 2010). Several miRNAs, transcriptionally activated by $\mathrm{p} 53$, contribute to the regulation of the p53-MDM2 feedback loop by targeting MDM2 directly, including miR-192, miR-194, miR-215, miR-605, miR-143 and miR-145 (Pichiorri et al., 2010; Xiao et al., 2011; Zhang et al., in press) (Figure 3). Expression of miRNAs miR-192, miR-194 and miR-215 contributes to activation of p53 target genes like p21 thereby promoting cell cycle arrest (Braun et al., 2008), partly via their suppression of MDM2. Repression of a number of additional cell cycle promoting targets also likely contribute the growth inhibitory function of these miRNAs (Georges et al., 2008). Furthermore, miR-192, miR-194 and miR-215 were found to be downregulated in multiple myeloma samples while downregulation of miRs-143/145 might contribute to formation of epithelial cancers (Pichiorri et al., 2010; Zhang et al., in press). In addition, induction of miR-145 by $\mathrm{p} 53$ was reported to play a role in the p53-mediated suppression of MYC, which is also a miR-145 target (Sachdeva et al., 2009).

Interestingly, transcriptional repression of pro-oncogenic miRNAs has also been evidenced, as the miR-17-92 polycistronic miRNA cluster (Concepcion et al., 2012a) can be suppressed by $\mathrm{p} 53$ at the transcriptional level, where p53 binding to the promoter occludes binding of the TATAbinding protein (Yan et al., 2009).

\subsubsection{Posttranscriptional regulation of miRNA expression during DNA damage}

The posttranscriptional regulation of miRNA during the DNA damage response has emerged to be of perhaps equal importance to that of transcriptional regulation in the control of miRNA levels. Observations that DNA damage leads to elevated levels of some pre-miRNAs and mature miRNAs with no significant alteration in the levels of their primary miRNA transcripts imply a link between the DNA damage response and miRNA processing and maturation and suggest that posttranscriptional mechanisms are likely to contribute to the induction of particular miRNAs during the DNA damage stress response (Suzuki et al., 2009; Zhang et al., 2011).

The first direct evidence that posttranscriptional processing of miRNAs impacts on the cellular response to UVinduced DNA damage was provided by a study noting that cells became hypersensitive to UV damage upon knockdown of Ago2 or Dicer (Pothof et al., 2009). Moreover, UV damage triggered a cell cycle dependent re-localisation of Ago2 into stress granules as well as changes in miRNA-expression (Pothof et al., 2009). Stress granules are intracellular proteinRNA aggregates that can form under stress conditions and they are proposed to regulate mRNA metabolism and act as storage centres for translationally repressed mRNAs (Anderson and Kedersha, 2008). Whether stress granules are directly involved in miRNA processing and mRNA suppression is still a mater of some debate (Pothof and van Gent, 2011). Interestingly, CDK but not ATM/ATR activity was essential for this alteration in Ago2 re-localisation, however ATM/ATR activity was necessary for induction of DNA damage inducible miRNA expression (Pothof et al., 2009). The changes in miRNA expression patterns and stress-granule formation were observed to take place very rapidly, within the first few hours following damage treatment, suggesting that miRNA regulation of the DNA damage response occurs earlier than the majority of transcriptional responses (Pothof et al., 2009). Thus miRNAs may be instrumental in co-ordinating the initial stages of the cellular response to DNA damage.

Another high impact study subsequently established, as mentioned above, that levels of several miRNAs were under posttranslational regulation by the p53 tumour suppressor protein in response to DNA damage (Suzuki et al., 2009). Following DNA damage, p53, by direct association with p68, enhances the posttranscriptional maturation of several miRNAs with growth-suppressive function, including miR16-1, miR-143 and miR-145 (Suzuki et al., 2009) (Figure 1B, Figure 2C). In addition, transcriptionally defective p53 mutants obstruct assembly of the Drosha complex and p68, diminishing miRNA processing activity (Suzuki et al., 2009). The majority of p53 mutations observed in cancers affect the domain required for both DNA binding and regulation of miRNA processing, thus it is difficult to separate and gauge the relative import of these two key p53 functions. It seems probable that loss of p53-mediated miRNA processing may work in concert with loss of transcriptional activity to facilitate tumourigenesis. Furthermore, critical proteins involved in miRNA biogenesis contain binding elements for p53, p63 and p73 in their promoters, suggesting that they could be transcriptionally regulated by this tumour suppressor family (Boominathan, 2010). Also the miRNA biogenesis factors themselves have been predicted to be targets of p53-induced miRNAs, which would establish a feedback effect to tightly control the levels of these damage responsive miRNAs (Boominathan, 2010). 
More recently it was demonstrated that around $25 \%$ of all miRNAs are induced in an ATM-dependent fashion following DNA damage (Zhang et al., 2011). This effect may be mediated in part by $\mathrm{KH}$-type splicing regulatory protein (KSRP), a constituent of both the Drosha and Dicer miRNA processing complexes (Trabucchi et al., 2009). ATM was shown to phosphorylate KSRP, resulting in an enhancement of the interaction between KSRP and pri-miRNAs and increased KSRP activity in miRNA processing leading to up-regulation of a specific group of miRNAs (Zhang et al., 2011).

Other kinases, such as CHK1 and CHK2, acting downstream of ATM/ATR in DNA damage signalling become activated and it seems likely that these too may regulate miRNA processing.

\subsection{3. miRNAs target genes involved in DNA damage regulation}

Many studies have shown that numerous crucial genes in the DNA damage response are regulated by their specific miRNAs.

The apical damage sensor kinase ATM itself was shown to be a target of miR-421 (Hu et al., 2010a). Cells from certain patients with ataxia-telangiectasia (A-T), a condition caused by deficient ATM activity, show increased expression of miR421 and blocking miR-421 binding to the ATM 3'UTR rescued the aberrant phenotype (Hu et al., 2010a). In addition, miR421 expression is upregulated in neuroblastoma as well as in large B-cell lymphoma cell lines as a result of the cells overexpressing the N-MYC oncogene (Hu et al., 2010a).

ATM phosphorylates a huge number of target genes (Matsuoka et al., 2007), among those is the histone variant $\mathrm{H} 2 \mathrm{AX}$, which has a key role in the response to DNA double strand breaks (DSBs) (Stucki et al., 2005). It numbers among the targets of the tumour suppressive miR-24, rendering cells hypersensitive to ionizing radiation and mimetic drugs (Lal et al., 2009b). Normally, miR-24 is upregulated in terminally differentiated cells, which show a reduced capability to repair DSBs (Lal et al., 2009b). In cancers loss of miR-24 would therefore confer a better resistance to genomic alterations. Indeed, expression of miR-24 is suppressed by MYC and lost in several cancers (Chang et al., 2008). Furthermore MYC, E2F1 and CDK4/6 are also described as targets for miR-24, negatively impacting on the cell cycle and contributing to its antitumourigenic effects (Lal et al., 2009a).

The tumour suppressor p53 is activated by various posttranscriptional mechanisms in response to DNA damage (Vousden and Lane, 2007) (Figure 2A). As a principal regulator of the cellular stress response, it acts as a transcription factor to regulate expression of a multitude of genes leading to cell cycle arrest, apoptosis and senescence (Vousden and Lane, 2007) (Figure 2B). There are also important transcriptionindependent functions of $\mathrm{p} 53$ in the induction of apoptosis and, as discussed above, in regulating the biogenesis of several miRNAs under damage conditions (Suzuki et al., 2009; Vousden and Lane, 2007) (Figure 2C).

Several reports describe that miRNAs can also negatively regulate p53 through direct interaction with the p53 3'UTR (Figure 3). The first report showed that miR-125b mediated downregulation of the $\mathrm{p} 53$ protein level suppressed apoptosis in human neuroblastoma cells and human lung fibroblast cells (Le et al., 2009). Thereafter, miR-504 was described to inhibit p53-mediated apoptosis and cell cycle arrest by directly targeting the p53 mRNA and in doing so promotes tumourigenicity of cells in vivo (Hu et al., 2010b). In addition, miR-380-5p, which is overexpressed in neuroblastomas due to MYCN amplification and associated with poor outcome, can also reduce p53 levels (Swarbrick et al., 2010). Members of the miR-30 family and miR-25 have also been found to negatively regulate p53 in some cell lines (Kumar et al., 2010; Li et al., 2010).

miRNAs capable of targeting negative regulators of p53 can lead to an enhancement of p53-dependent anti-proliferative effects (Figure 3) exemplified by miRNAs targeting MDM2 as discussed above. In addition, members of the miR-29 family for example were shown to target two potential negative regulators of p53; p85-alpha, the regulatory subunit of phosphatidylinositol-3 kinase (PI3K) and CDC42, positively impacting on p53-mediated apoptosis (Park et al., 2009). As mentioned above, miR-29 displays tumour suppressor activity also via targeting DNA methyltransferases (Fabbri et al., 2007). Furthermore, miR-29b is a regulator of the anti-apoptotic protein Mcl-1, which is upregulated in malignant cells in which miR-29b is concurrently downregulated (Mott et al., 2007). Additionally, miR-122 was reported to play a role in p53 activation by various mechanisms (Burns et al., 2011; Fornari et al., 2009).

\section{5. miRNAs in cancer diagnosis and therapy}

As the important roles of miRNAs in cancer are being deciphered their potential as prognostic or diagnostics markers is evidenced by a long list of studies. Furthermore, therapeutics strategies involving re-introduction of miRNAs lost in cancer or inhibition of oncogenic miRNAs are rapidly being developed.

Early transcriptional profiling data evidenced that microRNA expression profiling may successfully classify different tumour types and do so more reliably than mRNA profiling, suggesting that the miRNA repertoire is a stable and unique feature of different cell types and differentiation stages (Lu et al., 2005; Olson et al., 2009). Since then, an extensive bulk of literature has reported on specific miRNA signatures for individual cancers and cancer stages (Iorio and Croce, 2012; Kong et al., 2012). Because of their stability in formalinfixed tissues and the relative ease by which they can be routinely quantified, miRNAs are quickly entering clinical laboratories as important tools for diagnostics and prognostics. Importantly, the cell and cancer-type specificity of miRNA expression profiles also holds a promise for the efficient identification of metastatic cancers of unknown primary origin (Ferracin et al., 2011; Rosenfeld et al., 2008). Recently, the discovery of miRNAs in body fluids, such as serum, urine and colostrum (Hanke et al., 2010; Lawrie et al., 2008; Link et al., 2010; Mitchell et al., 2008), has intensified investigations into the use of miRNAs as non-invasive biomarkers of disease and therapeutic response in a range of cancers including lung cancer (Chen et al., 2008), ovarian cancer (Resnick et al., 2009), colorectal cancer (Ng et al., 2009), renal cancer (Feng et al., 2008), glioblastoma (Skog et al., 2008), prostate cancer (Mitchell et al., 2008) and breast cancer (Cortez et al., 2012). 
We focus here on the current developments in using miRNA mimics or inhibitors for the treatment of cancer.

\subsection{Inhibition of pro-oncogenic miRNAs}

Inhibition of overexpressed miRNAs causally linked to tumourigenic processes has been reported from a multitude of xenograft studies covering different cancer form. Studies on the inhibition of endogenous miRNA were pioneered by groups studying the liver-specific miR-122 and its roles in controlling plasma cholesterol levels and facilitating Hepatitis C virus replication (Elmen et al., 2008a; Krutzfeldt et al., 2005; Lanford et al., 2010). Using intravenous injections of cholesterol-conjugated single stranded antagomirs stabilized by 2 'O-methylations, Krüztfeldt et al. demonstrated specific relieve of repression of mRNAs containing recognition motifs matching the inhibited miRNA in several tissues. Furthermore, inhibition of the liver-specific miR-122 resulted in reduced levels of plasma cholesterol in agreement with the function of the targeted mRNAs. Corroborating and extending on this work, Kauppinen and co-workers used locked nucleic acid (LNA) antimiRs against miR-122 in both mice and primates (Elmen et al., 2008a, 2008b; Lanford et al., 2010).

Whereas numerous studies have used preclinical models, primarily mouse xenografts, to causally link a particular miRNAs to a cancerous phenotype by transfecting cancer cells with miRNAs or miRNA inhibitors prior to infusion in mice, we will focus here on studies taking a more therapeutic approach, such as systemic or targeted treatments. As for several other drug forms, a major challenge in exploiting miRNA for therapeutics is the biodistribution of the drugs and the targeted delivery of miRNA mimics or inhibitors to tumour cells in vivo.

In a pioneering study of using systemic treatment with miRNA inhibitors in a cancer setting, Weinberg and colleagues identified miR-10b as overexpressed in metastatic breast cancer and showed that overexpression of miR-10b alone can confer metastatic potential to otherwise non-invasive cell lines (Ma et al., 2007). Extending on this work, the group demonstrated that therapeutic treatment (intravenous injections) with cholesterol-conjugated 2'O-methyl-derived inhibitors of miR-10b of immunocompromized mice transplanted with a highly metastatic breast cancer cell line in the mammary fat pad resulted in a robust inhibition of metastasis to the lung while leaving tumour growth at the primary site of infusion unaffected (Ma et al., 2010).

Along similar lines, using a xenograft model for hepatocellular carcinoma, an inhibitor against miR-221 resulted in reduced tumour cell proliferation in vivo accompanied by an elevated level of tumour cell apoptosis (Park et al., 2011).

miR-9 is found upregulated in several cancer forms including Hodgkin lymphoma. Using a mouse xenograft model for Hodgkin lymphoma it was demonstrated that systemic treatment using an LNA-derived inhibitor of miR-9 significantly reduced lymphoma outgrowth in the liver and resulted in the upregulation of important miR-9 target mRNAs (Leucci et al., in press). In addition, miRNA inhibition strategies have also shown positive effects against brain-derived tumours, such as for miR-380-5p in neuroblastoma (Swarbrick et al., 2010) and for miR-296 in glioma (Wurdinger et al., 2008), respectively.
Using another chemistry to stabilize and package miRNA inhibitors, slack and colleagues recently deployed inhibitors to miR-155 based on peptide nucleic acids and encapsulated in nanoparticles to show diminish tumour outgrowth of both xenograft and orthograft models of lymphoma (Babar et al., 2012).

\subsection{Reintroduction of tumour-suppressive miRNAs}

Reintroduction of miRNAs with tumour-suppressive function is, aside from the issue of tumour cell targeting, further complicated by the rapid degradation of RNA in tissues and serum. Hence, there has been considerable interest in viral delivery methods and in formulated miRNA mimics (Thorsen et al., 2012).

The let-7 miRNA family is downregulated in many cancers and has been shown to target prominent oncogenes, such as KRAS, MYC and HMGA2 (Johnson et al., 2005; Park et al., 2007; Sampson et al., 2007). Hence, restoring let-7 levels in tumours is an attractive therapeutic option. In accordance, both lipid-formulated let- $7 \mathrm{~b}$ and lentiviral expression of let-7a resulted in reduced tumour burden in a KRas-driven model of lung cancer (Trang et al., 2010, 2011).

As described above, the miR-34 family is considered important tumour-suppressors with multiple targets in key cancer pathways (Hermeking, 2012). Corroborating these findings, reintroduction of lipid-formulated miR-34 in both a spontaneous lung cancer model and in a xenograft model using pancreatic cancer cells resulted in reduced tumour growth (Liu et al., 2011; Trang et al., 2011).

The cistronic miR-143/145 cluster has likewise been found lost across many different cancers and their re-expression is considered a promising mode of therapy (Kitade and Akao, 2010). Sustaining this notion, systemic administration of a liposome-formulated miR-143/145 expression vector resulted in reduced outgrowth of pancreatic cancer xenografts (Pramanik et al., 2011).

In hepatocellular carcinoma the level of miR-26a is reduced in accordance with its function as a repressor of the key cyclins cyclin D2 and E2 (Kota et al., 2009). The therapeutic potential of reintroducing miR-26a was demonstrated in mouse model for hepatocellular carcinoma, where systemic delivery of miR-26a expressed from an adeno-associated viral vector resulted in inhibited cancer cell proliferation and induction of apoptosis (Kota et al., 2009). However, as miRNAs have many downstream targets, manipulating their expression level may have pleiotropic effects. In the case of miR-26a, the gene is frequently amplified in gliomas (Huse et al., 2009) and overexpression of miR-26a has been found to increase the metastatic potential of lung cancer cells and to promote the development of T-cell lymphoblastic leukaemia likely via repression of the PTEN tumour suppressor (Liu et al., 2012; Mavrakis et al., 2011).

Hence, miRNA is emerging as an important family of molecules with promising perspectives for therapy in cancer. However, as for other drug classes, the efficacy and safety of miRNA-derived drugs must be carefully assessed and will most likely depend on cellular context and pre-existing genetic and epigenetic lesions. 


\section{Concluding remarks}

A decade of miRNA research has advanced the field from initial discovery of this important group of regulators across all multicellular species to the stage where miRNA-based procedures are rapidly entering the clinic as important diagnostic and promising therapeutic tools. Although gaps still exist in our understanding of how this posttranscriptional mechanism of gene expression works and how it is regulated in different cell types, an overwhelming amount of data strongly links deregulated miRNA expression to the aetiology of many cancers. The emerging picture suggests that miRNA as such, via their important roles in defining expression boundaries and driving differentiation processes, are key players in cell fate decisions and maintenance and hereby counteracts the plasticity and de-differentiation processes underlying oncogenesis. Furthermore, miRNAs are strongly linked to the engine room of cancer, affecting nodal points in cell cycle regulation, genome integrity and stress responses, apoptosis and metastasis. In addition, genetic models have evidenced that several miRNAs act as bone fide oncogenes and that tumours may develop addiction to oncogenic miRNA overexpression, which holds a promise for the therapeutic use of miRNA inhibitors. Although we still have a way to go in identifying key miRNAs of clinical importance in various cancers, the rapid development of the field is likely to advance many preclinical projects to humans in the near future. A potential caveat could be that while many of the currently used drug types have broad effects and may influence several cellular pathways, miRNA are intrinsically hard-wired to regulate cohorts of targets often resulting in pleiotropic effects. Furthermore, our understanding of the functions of the majority of miRNAs comes only from limited studies in cell culture models and clearly we must explore their dependency on cellular context and study their interplay within prevalent cancer lesions. The next decade should be interesting too!

\section{Acknowledgements}

Work in the authors' laboratory is supported by the Danish National Research Foundation, the Danish National Advanced Technology Foundation, the Novo Nordisk Foundation, the EC FP7 programs (ONCOMIRS, grant agreement number 201102. This publication reflects only authors' views. The commission is not liable for any use that may be made of the information herein.), the Lundbeck Foundation, and the Danish Cancer Society.

\section{R E F E R E N C E S}

Alvarez-Saavedra, E., Horvitz, H.R., 2010. Many families of C. elegans microRNAs are not essential for development or viability. Curr. Biol. 20, 367-373.

Anderson, P., Kedersha, N., 2008. Stress granules: the Tao of RNA triage. Trends Biochem. Sci. 33, 141-150.

Anokye-Danso, F., Trivedi, C.M., Juhr, D., Gupta, M., Cui, Z., Tian, Y., Zhang, Y., Yang, W., Gruber, P.J., Epstein, J.A.,
Morrisey, E.E., 2011. Highly efficient miRNA-mediated reprogramming of mouse and human somatic cells to pluripotency. Cell Stem Cell 8, 376-388.

Babar, I.A., Cheng, C.J., Booth, C.J., Liang, X., Weidhaas, J.B., Saltzman, W.M., Slack, F.J., 2012. Nanoparticle-based therapy in an in vivo microRNA-155 (miR-155)-dependent mouse model of lymphoma. Proc. Natl. Acad. Sci. USA 109, E1695-E1704.

Bartel, D.P., 2009. MicroRNAs: target recognition and regulatory functions. Cell 136, 215-233.

Benetti, R., Gonzalo, S., Jaco, I., Munoz, P., Gonzalez, S., Schoeftner, S., Murchison, E., Andl, T., Chen, T., Klatt, P., Li, E., Serrano, M., Millar, S., Hannon, G., Blasco, M.A., 2008. A mammalian microRNA cluster controls DNA methylation and telomere recombination via Rbl2-dependent regulation of DNA methyltransferases. Nat. Struct. Mol. Biol. 15, 998.

Bommer, G.T., Gerin, I., Feng, Y., Kaczorowski, A.J., Kuick, R., Love, R.E., Zhai, Y., Giordano, T.J., Qin, Z.S., Moore, B.B., MacDougald, O.A., Cho, K.R., Fearon, E.R., 2007. p53-mediated activation of miRNA34 candidate tumor-suppressor genes. Curr. Biol. 17, 1298-1307.

Boominathan, L., 2010. The tumor suppressors p53, p63, and p73 are regulators of microRNA processing complex. PLoS One 5, e10615.

Bou Kheir, T., Futoma-Kazmierczak, E., Jacobsen, A., Krogh, A., Bardram, L., Hother, C., Gronbaek, K., Federspiel, B., Lund, A.H., Friis-Hansen, L., 2011. miR-449 inhibits cell proliferation and is down-regulated in gastric cancer. Mol. Cancer 10, 29.

Bracken, C.P., Gregory, P.A., Kolesnikoff, N., Bert, A.G., Wang, J., Shannon, M.F., Goodall, G.J., 2008. A double-negative feedback loop between ZEB1-SIP1 and the microRNA-200 family regulates epithelial-mesenchymal transition. Cancer Res. 68, 7846-7854.

Braun, C.J., Zhang, X., Savelyeva, I., Wolff, S., Moll, U.M., Schepeler, T., Orntoft, T.F., Andersen, C.L., Dobbelstein, M., 2008. p53-Responsive microRNAs 192 and 215 are capable of inducing cell cycle arrest. Cancer Res. 68, 10094-10104.

Brooks, C.L., Gu, W., 2009. How does SIRT1 affect metabolism, senescence and cancer? Nat. Rev. Cancer 9, 123-128.

Brueckner, B., Stresemann, C., Kuner, R., Mund, C., Musch, T., Meister, M., Sultmann, H., Lyko, F., 2007. The human let-7a-3 locus contains an epigenetically regulated microRNA gene with oncogenic function. Cancer Res. 67, 1419-1423.

Bueno, M.J., Gomez de Cedron, M., Laresgoiti, U., FernandezPiqueras, J., Zubiaga, A.M., Malumbres, M., 2010. Multiple E2F-induced microRNAs prevent replicative stress in response to mitogenic signaling. Mol. Cell. Biol. 30, 2983-2995.

Bueno, M.J., Malumbres, M., 2011. MicroRNAs and the cell cycle. Biochim. Biophys. Acta 1812, 592-601.

Bui, T.V., Mendell, J.T., 2010. Myc: maestro of microRNAs. Genes Cancer 1, 568-575.

Burk, U., Schubert, J., Wellner, U., Schmalhofer, O., Vincan, E., Spaderna, S., Brabletz, T., 2008. A reciprocal repression between ZEB1 and members of the miR-200 family promotes EMT and invasion in cancer cells. EMBO Rep. 9, 582-589.

Burns, D.M., D'Ambrogio, A., Nottrott, S., Richter, J.D., 2011. CPEB and two poly(A) polymerases control miR-122 stability and p53 mRNA translation. Nature 473, 105-108.

Calin, G.A., Dumitru, C.D., Shimizu, M., Bichi, R., Zupo, S., Noch, E., Aldler, H., Rattan, S., Keating, M., Rai, K., Rassenti, L., Kipps, T., Negrini, M., Bullrich, F., Croce, C.M., 2002. Frequent deletions and down-regulation of micro-RNA genes miR15 and miR16 at 13q14 in chronic lymphocytic leukemia. Proc. Natl. Acad. Sci. USA 99, 15524-15529.

Calin, G.A., Liu, C.G., Ferracin, M., Hyslop, T., Spizzo, R., Sevignani, C., Fabbri, M., Cimmino, A., Lee, E.J., Wojcik, S.E., Shimizu, M., Tili, E., Rossi, S., Taccioli, C., Pichiorri, F., Liu, X., Zupo, S., Herlea, V., Gramantieri, L., Lanza, G., Alder, H., 
Rassenti, L., Volinia, S., Schmittgen, T.D., Kipps, T.J., Negrini, M., Croce, C.M., 2007. Ultraconserved regions encoding ncRNAs are altered in human leukemias and carcinomas. Cancer Cell 12, 215-229.

Calin, G.A., Sevignani, C., Dumitru, C.D., Hyslop, T., Noch, E., Yendamuri, S., Shimizu, M., Rattan, S., Bullrich, F., Negrini, M., Croce, C.M., 2004. Human microRNA genes are frequently located at fragile sites and genomic regions involved in cancers. Proc. Natl. Acad. Sci. USA 101, 2999-3004.

Castellano, L., Giamas, G., Jacob, J., Coombes, R.C., Lucchesi, W., Thiruchelvam, P., Barton, G., Jiao, L.R., Wait, R., Waxman, J., Hannon, G.J., Stebbing, J., 2009. The estrogen receptor-alphainduced microRNA signature regulates itself and its transcriptional response. Proc. Natl. Acad. Sci. USA 106, 15732-15737.

Chang, C.J., Chao, C.H., Xia, W., Yang, J.Y., Xiong, Y., Li, C.W., Yu, W.H., Rehman, S.K., Hsu, J.L., Lee, H.H., Liu, M., Chen, C.T., Yu, D., Hung, M.C., 2011. p53 regulates epithelialmesenchymal transition and stem cell properties through modulating miRNAs. Nat. Cell. Biol. 13, 317-323.

Chang, T.C., Wentzel, E.A., Kent, O.A., Ramachandran, K., Mullendore, M., Lee, K.H., Feldmann, G., Yamakuchi, M., Ferlito, M., Lowenstein, C.J., Arking, D.E., Beer, M.A., Maitra, A., Mendell, J.T., 2007. Transactivation of miR-34a by p53 broadly influences gene expression and promotes apoptosis. Mol. Cell. 26, 745-752.

Chang, T.C., Yu, D., Lee, Y.S., Wentzel, E.A., Arking, D.E., West, K.M., Dang, C.V., Thomas-Tikhonenko, A., Mendell, J.T., 2008. Widespread microRNA repression by Myc contributes to tumorigenesis. Nat. Genet. 40, 43-50.

Chang, T.C., Zeitels, L.R., Hwang, H.W., Chivukula, R.R., Wentzel, E.A., Dews, M., Jung, J., Gao, P., Dang, C.V., Beer, M.A., Thomas-Tikhonenko, A., Mendell, J.T., 2009. Lin-28B transactivation is necessary for Myc-mediated let-7 repression and proliferation. Proc. Natl. Acad. Sci. USA 106, 3384-3389.

Chen, X., Ba, Y., Ma, L., Cai, X., Yin, Y., Wang, K., Guo, J., Zhang, Y., Chen, J., Guo, X., Li, Q., Li, X., Wang, W., Zhang, Y., Wang, J., Jiang, X., Xiang, Y., Xu, C., Zheng, P., Zhang, J., Li, R., Zhang, H., Shang, X., Gong, T., Ning, G., Wang, J., Zen, K., Zhang, J., Zhang, C.Y., 2008. Characterization of microRNAs in serum: a novel class of biomarkers for diagnosis of cancer and other diseases. Cell Res. 18, 997-1006.

Chendrimada, T.P., Gregory, R.I., Kumaraswamy, E., Norman, J., Cooch, N., Nishikura, K., Shiekhattar, R., 2005. TRBP recruits the Dicer complex to Ago2 for microRNA processing and gene silencing. Nature 436, 740-744.

Chin, L.J., Ratner, E., Leng, S., Zhai, R., Nallur, S., Babar, I., Muller, R.U., Straka, E., Su, L., Burki, E.A., Crowell, R.E., Patel, R., Kulkarni, T., Homer, R., Zelterman, D., Kidd, K.K., Zhu, Y., Christiani, D.C., Belinsky, S.A., Slack, F.J., Weidhaas, J.B., 2008. A SNP in a let-7 microRNA complementary site in the KRAS 3' untranslated region increases non-small cell lung cancer risk. Cancer Res. 68, 8535-8540.

Chiosea, S., Jelezcova, E., Chandran, U., Acquafondata, M., McHale, T., Sobol, R.W., Dhir, R., 2006. Up-regulation of dicer, a component of the MicroRNA machinery, in prostate adenocarcinoma. Am. J. Pathol. 169, 1812-1820.

Christoffersen, N.R., Shalgi, R., Frankel, L.B., Leucci, E., Lees, M., Klausen, M., Pilpel, Y., Nielsen, F.C., Oren, M., Lund, A.H., 2009. p53-independent upregulation of miR-34a during oncogeneinduced senescence represses MYC. Cell. Death Differ. 17, 236-245.

Christoffersen, N.R., Silahtaroglu, A., Orom, U.A., Kauppinen, S., Lund, A.H., 2007. miR-200b mediates post-transcriptional repression of ZFHX1B. RNA 13, 1172-1178.

Concepcion, C.P., Bonetti, C., Ventura, A., 2012a. The microRNA17-92 family of microRNA clusters in development and disease. Cancer J. 18, 262-267.
Concepcion, C.P., Han, Y.C., Mu, P., Bonetti, C., Yao, E., D’Andrea, A., Vidigal, J.A., Maughan, W.P., Ogrodowski, P., Ventura, A., 2012b. Intact p53-dependent responses in mir-34deficient mice. PLoS Genet. 8, e1002797.

Cordes, K.R., Sheehy, N.T., White, M.P., Berry, E.C., Morton, S.U., Muth, A.N., Lee, T.H., Miano, J.M., Ivey, K.N., Srivastava, D., 2009. miR-145 and miR-143 regulate smooth muscle cell fate and plasticity. Nature 460, 705-710.

Corney, D.C., Flesken-Nikitin, A., Godwin, A.K., Wang, W., Nikitin, A.Y., 2007. MicroRNA-34b and MicroRNA-34c are targets of p53 and cooperate in control of cell proliferation and adhesion-independent growth. Cancer Res. 67, 8433-8438.

Corney, D.C., Hwang, C.I., Matoso, A., Vogt, M., FleskenNikitin, A., Godwin, A.K., Kamat, A.A., Sood, A.K., Ellenson, L.H., Hermeking, H., Nikitin, A.Y., 2010. Frequent downregulation of miR-34 family in human ovarian cancers. Clin. Cancer Res.: J. Am. Assoc. Cancer Res. 16, 1119-1128.

Cortez, M.A., Welsh, J.W., Calin, G.A., 2012. Circulating microRNAs as noninvasive biomarkers in breast cancer. Recent Results in Cancer Research. Fortschritte der Krebsforschung. Progres dans les recherches sur le cancer 195, 151-161.

Costinean, S., Zanesi, N., Pekarsky, Y., Tili, E., Volinia, S., Heerema, N., Croce, C.M., 2006. Pre-B cell proliferation and lymphoblastic leukemia/high-grade lymphoma in $\mathrm{E}(\mathrm{mu})$ miR155 transgenic mice. Proc. Natl. Acad. Sci. USA 103, 7024-7029.

Croce, C.M., 2009. Causes and consequences of microRNA dysregulation in cancer. Nat. Rev. Genet. 10, 704-714.

Davis, B.N., Hilyard, A.C., Lagna, G., Hata, A., 2008. SMAD proteins control DROSHA-mediated microRNA maturation. Nature 454, 56-61.

Dews, M., Homayouni, A., Yu, D., Murphy, D., Sevignani, C., Wentzel, E., Furth, E.E., Lee, W.M., Enders, G.H., Mendell, J.T., Thomas-Tikhonenko, A., 2006. Augmentation of tumor angiogenesis by a Myc-activated microRNA cluster. Nat. Genet. 38, 1060-1065.

Diederichs, S., Haber, D.A., 2006. Sequence variations of microRNAs in human cancer: alterations in predicted secondary structure do not affect processing. Cancer Res. 66, 6097-6104.

Elmen, J., Lindow, M., Schutz, S., Lawrence, M., Petri, A., Obad, S., Lindholm, M., Hedtjarn, M., Hansen, H.F., Berger, U., Gullans, S., Kearney, P., Sarnow, P., Straarup, E.M., Kauppinen, S., 2008a. LNA-mediated microRNA silencing in non-human primates. Nature 452, 896-899.

Elmen, J., Lindow, M., Silahtaroglu, A., Bak, M., Christensen, M., Lind-Thomsen, A., Hedtjarn, M., Hansen, J.B., Hansen, H.F., Straarup, E.M., McCullagh, K., Kearney, P., Kauppinen, S., 2008b. Antagonism of microRNA-122 in mice by systemically administered LNA-antimiR leads to up-regulation of a large set of predicted target mRNAs in the liver. Nucleic Acids Res. 36, 1153-1162.

Fabbri, M., Garzon, R., Cimmino, A., Liu, Z., Zanesi, N., Callegari, E., Liu, S., Alder, H., Costinean, S., FernandezCymering, C., Volinia, S., Guler, G., Morrison, C.D., Chan, K.K., Marcucci, G., Calin, G.A., Huebner, K., Croce, C.M., 2007. MicroRNA-29 family reverts aberrant methylation in lung cancer by targeting DNA methyltransferases 3A and 3B. Proc. Natl. Acad. Sci. USA 104, 15805-15810.

Fabian, M.R., Sonenberg, N., 2012. The mechanics of miRNAmediated gene silencing: a look under the hood of miRISC. Nat. Struct. Mol. Biol. 19, 586-593.

Faraoni, I., Antonetti, F.R., Cardone, J., Bonmassar, E., 2009. miR155 gene: a typical multifunctional microRNA. Biochim. Biophys. Acta 1792, 497-505.

Fazi, F., Racanicchi, S., Zardo, G., Starnes, L.M., Mancini, M., Travaglini, L., Diverio, D., Ammatuna, E., Cimino, G., Lo-Coco, F., Grignani, F., Nervi, C., 2007. Epigenetic silencing of 
the myelopoiesis regulator microRNA-223 by the AML1/ETO oncoprotein. Cancer Cell 12, 457-466.

Feng, G., Li, G., Gentil-Perret, A., Tostain, J., Genin, C., 2008. Elevated serum-circulating RNA in patients with conventional renal cell cancer. Anticancer Res. 28, 321-326.

Ferracin, M., Pedriali, M., Veronese, A., Zagatti, B., Gafa, R., Magri, E., Lunardi, M., Munerato, G., Querzoli, G., Maestri, I., Ulazzi, L., Nenci, I., Croce, C.M., Lanza, G., Querzoli, P., Negrini, M., 2011. MicroRNA profiling for the identification of cancers with unknown primary tissue-of-origin. J. Pathol. 225, $43-53$.

Fornari, F., Gramantieri, L., Giovannini, C., Veronese, A., Ferracin, M., Sabbioni, S., Calin, G.A., Grazi, G.L., Croce, C.M., Tavolari, S., Chieco, P., Negrini, M., Bolondi, L., 2009. MiR-122/ cyclin G1 interaction modulates p53 activity and affects doxorubicin sensitivity of human hepatocarcinoma cells. Cancer Res. 69, 5761-5767.

Frankel, L.B., Christoffersen, N.R., Jacobsen, A., Lindow, M., Krogh, A., Lund, A.H., 2008. Programmed cell death 4 (PDCD4) is an important functional target of the microRNA miR-21 in breast cancer cells. J. Biol. Chem. 283, 1026-1033.

Frankel, L.B., Lund, A.H. MicroRNA regulation of Autophagy. Carcinogenesis, in press.

Galardi, S., Mercatelli, N., Giorda, E., Massalini, S., Frajese, G.V., Ciafre, S.A., Farace, M.G., 2007. miR-221 and miR-222 expression affects the proliferation potential of human prostate carcinoma cell lines by targeting p27Kip1. J. Biol. Chem. 282, 23716-23724.

Gallardo, E., Navarro, A., Vinolas, N., Marrades, R.M., Diaz, T., Gel, B., Quera, A., Bandres, E., Garcia-Foncillas, J., Ramirez, J., Monzo, M., 2009. miR-34a as a prognostic marker of relapse in surgically resected non-small-cell lung cancer. Carcinogenesis 30, 1903-1909.

Garre, P., Perez-Segura, P., Diaz-Rubio, E., Caldes, T., de la Hoya, M., 2010. Reassessing the TARBP2 mutation rate in hereditary nonpolyposis colorectal cancer. Nat. Genet. 42, 817-818. author reply 818.

Gebeshuber, C.A., Zatloukal, K., Martinez, J., 2009. miR-29a suppresses tristetraprolin, which is a regulator of epithelial polarity and metastasis. EMBO Rep. 10, 400-405.

Genovese, C., Trani, D., Caputi, M., Claudio, P.P., 2006. Cell cycle control and beyond: emerging roles for the retinoblastoma gene family. Oncogene 25, 5201-5209.

Georges, S.A., Biery, M.C., Kim, S.Y., Schelter, J.M., Guo, J., Chang, A.N., Jackson, A.L., Carleton, M.O., Linsley, P.S., Cleary, M.A., Chau, B.N., 2008. Coordinated regulation of cell cycle transcripts by p53-Inducible microRNAs, miR-192 and miR-215. Cancer Res. 68, 10105-10112.

Gillies, J.K., Lorimer, I.A., 2007. Regulation of p27Kip1 by miRNA 221/222 in glioblastoma. Cell Cycle 6, 2005-2009.

Griffiths-Jones, S., 2010. miRBase: microRNA sequences and annotation. In: Baxevanis, Andreas D., et al. (Eds.), Current Protocols in Bioinformatics/Editoral Board, vol. 19, pp. 10-11. Chapter 12, Unit 12.

Hanke, M., Hoefig, K., Merz, H., Feller, A.C., Kausch, I., Jocham, D., Warnecke, J.M., Sczakiel, G., 2010. A robust methodology to study urine microRNA as tumor marker: microRNA-126 and microRNA-182 are related to urinary bladder cancer. Urol. Oncol. 28, 655-661.

Hatley, M.E., Patrick, D.M., Garcia, M.R., Richardson, J.A., BasselDuby, R., van Rooij, E., Olson, E.N., 2010. Modulation of K-Rasdependent lung tumorigenesis by MicroRNA-21. Cancer Cell 18, 282-293.

He, L., He, X., Lim, L.P., de Stanchina, E., Xuan, Z., Liang, Y., Xue, W., Zender, L., Magnus, J., Ridzon, D., Jackson, A.L., Linsley, P.S., Chen, C., Lowe, S.W., Cleary, M.A., Hannon, G.J., 2007a. A microRNA component of the p53 tumour suppressor network. Nature 447, 1130-1134.
He, L., He, X., Lowe, S.W., Hannon, G.J., 2007b. microRNAs join the p53 network - another piece in the tumour-suppression puzzle. Nat. Rev. Cancer 7, 819-822.

He, L., Thomson, J.M., Hemann, M.T., Hernando-Monge, E., $\mathrm{Mu}$, D., Goodson, S., Powers, S., Cordon-Cardo, C., Lowe, S.W., Hannon, G.J., Hammond, S.M., 2005. A microRNA polycistron as a potential human oncogene. Nature 435 , 828-833.

Heinrich, E.M., Dimmeler, S., 2012. MicroRNAs and stem cells: control of pluripotency, reprogramming, and lineage commitment. Circ. Res. 110, 1014-1022.

Henley, S.A., Dick, F.A., 2012. The retinoblastoma family of proteins and their regulatory functions in the mammalian cell division cycle. Cell Div. 7, 10.

Hermeking, H., 2010. The miR-34 family in cancer and apoptosis. Cell. Death. Differ. 17, 193-199.

Hermeking, H., 2012. MicroRNAs in the p53 network: micromanagement of tumour suppression. Nat. Rev. Cancer $12,613-626$.

Herranz, H., Cohen, S.M., 2010. MicroRNAs and gene regulatory networks: managing the impact of noise in biological systems. Genes Dev. 24, 1339-1344.

Hornstein, E., Shomron, N., 2006. Canalization of development by microRNAs. Nat. Genet. 38 (Suppl. 1), S20-S24.

Hu, H., Du, L., Nagabayashi, G., Seeger, R.C., Gatti, R.A., 2010a. ATM is down-regulated by N-Myc-regulated microRNA-421 Proc. Natl. Acad. Sci. USA 107, 1506-1511.

Hu, W., Chan, C.S., Wu, R., Zhang, C., Sun, Y., Song, J.S., Tang, L.H., Levine, A.J., Feng, Z., 2010b. Negative regulation of tumor suppressor p53 by microRNA miR-504. Mol. Cell. 38, 689-699.

Huang, L., Luo, J., Cai, Q., Pan, Q., Zeng, H., Guo, Z., Dong, W., Huang, J., Lin, T., 2011. MicroRNA-125b suppresses the development of bladder cancer by targeting E2F3. Int. J. Cancer 128, 1758-1769.

Huse, J.T., Brennan, C., Hambardzumyan, D., Wee, B., Pena, J., Rouhanifard, S.H., Sohn-Lee, C., le Sage, C., Agami, R., Tuschl, T., Holland, E.C., 2009. The PTEN-regulating microRNA miR-26a is amplified in high-grade glioma and facilitates gliomagenesis in vivo. Genes Dev. 23, 1327-1337.

Iliopoulos, D., Lindahl-Allen, M., Polytarchou, C., Hirsch, H.A., Tsichlis, P.N., Struhl, K., 2010. Loss of miR-200 inhibition of Suz12 leads to polycomb-mediated repression required for the formation and maintenance of cancer stem cells. Mol. Cell. 39, 761-772.

Iorio, M.V., Croce, C.M., 2012. MicroRNA dysregulation in cancer: diagnostics, monitoring and therapeutics. A comprehensive review. EMBO Mol. Med. 4, 143-159.

Iorio, M.V., Visone, R., Di Leva, G., Donati, V., Petrocca, F., Casalini, P., Taccioli, C., Volinia, S., Liu, C.G., Alder, H., Calin, G.A., Menard, S., Croce, C.M., 2007. MicroRNA signatures in human ovarian cancer. Cancer Res. 67, 8699-8707.

Ivanovska, I., Ball, A.S., Diaz, R.L., Magnus, J.F., Kibukawa, M., Schelter, J.M., Kobayashi, S.V., Lim, L., Burchard, J., Jackson, A.L., Linsley, P.S., Cleary, M.A., 2008. MicroRNAs in the miR-106b family regulate p21/CDKN1A and promote cell cycle progression. Mol. Cell. Biol. 28, 2167-2174.

Johnson, C.D., Esquela-Kerscher, A., Stefani, G., Byrom, M., Kelnar, K., Ovcharenko, D., Wilson, M., Wang, X., Shelton, J., Shingara, J., Chin, L., Brown, D., Slack, F.J., 2007. The let-7 microRNA represses cell proliferation pathways in human cells. Cancer Res. 67, 7713-7722.

Johnson, S.M., Grosshans, H., Shingara, J., Byrom, M., Jarvis, R., Cheng, A., Labourier, E., Reinert, K.L., Brown, D., Slack, F.J., 2005. RAS is regulated by the let-7 microRNA family. Cell 120, 635-647.

Kanellopoulou, C., Muljo, S.A., Kung, A.L., Ganesan, S., Drapkin, R., Jenuwein, T., Livingston, D.M., Rajewsky, K., 2005 Dicer-deficient mouse embryonic stem cells are defective in 
differentiation and centromeric silencing. Genes Dev. 19, 489-501.

Karube, Y., Tanaka, H., Osada, H., Tomida, S., Tatematsu, Y., Yanagisawa, K., Yatabe, Y., Takamizawa, J., Miyoshi, S., Mitsudomi, T., Takahashi, T., 2005. Reduced expression of Dicer associated with poor prognosis in lung cancer patients. Cancer Sci. 96, 111-115.

Kasinski, A.L., Slack, F.J., 2011. Epigenetics and genetics. MicroRNAs en route to the clinic: progress in validating and targeting microRNAs for cancer therapy. Nat. Rev. Cancer 11, 849-864.

Kastan, M.B., Bartek, J., 2004. Cell-cycle checkpoints and cancer. Nature 432, 316-323.

Kedde, M., Strasser, M.J., Boldajipour, B., Oude Vrielink, J.A., Slanchev, K., le Sage, C., Nagel, R., Voorhoeve, P.M., van Duijse, J., Orom, U.A., Lund, A.H., Perrakis, A., Raz, E., Agami, R., 2007. RNA-binding protein Dnd1 inhibits microRNA access to target mRNA. Cell 131, 1273-1286.

Kedde, M., van Kouwenhove, M., Zwart, W., Oude Vrielink, J.A., Elkon, R., Agami, R., 2010. A Pumilio-induced RNA structure switch in p27-3' UTR controls miR-221 and miR-222 accessibility. Nat. Cell. Biol. 12, 1014-1020.

Kent, O.A., Chivukula, R.R., Mullendore, M., Wentzel, E.A., Feldmann, G., Lee, K.H., Liu, S., Leach, S.D., Maitra, A., Mendell, J.T., 2010. Repression of the miR-143/145 cluster by oncogenic Ras initiates a tumor-promoting feed-forward pathway. Genes Dev. 24, 2754-2759.

Kim, H.H., Kuwano, Y., Srikantan, S., Lee, E.K., Martindale, J.L., Gorospe, M., 2009a. HuR recruits let-7/RISC to repress c-Myc expression. Genes Dev. 23, 1743-1748.

Kim, V.N., Han, J., Siomi, M.C., 2009b. Biogenesis of small RNAs in animals. Nat. Rev. Mol. Cell. Biol. 10, 126-139.

Kim, Y.K., Yu, J., Han, T.S., Park, S.Y., Namkoong, B., Kim, D.H., Hur, K., Yoo, M.W., Lee, H.J., Yang, H.K., Kim, V.N., 2009c. Functional links between clustered microRNAs: suppression of cell-cycle inhibitors by microRNA clusters in gastric cancer. Nucleic Acids Res. 37, 1672-1681.

Kitade, Y., Akao, Y., 2010. MicroRNAs and their therapeutic potential for human diseases: microRNAs, miR-143 and -145, function as anti-oncomirs and the application of chemically modified miR143 as an anti-cancer drug. J. Pharmacol. Sci. 114, 276-280.

Kong, Y.W., Ferland-McCollough, D., Jackson, T.J., Bushell, M., 2012. microRNAs in cancer management. Lancet Oncol. 13, e249-e258.

Kota, J., Chivukula, R.R., O’Donnell, K.A., Wentzel, E.A., Montgomery, C.L., Hwang, H.W., Chang, T.C., Vivekanandan, P., Torbenson, M., Clark, K.R., Mendell, J.R., Mendell, J.T., 2009. Therapeutic microRNA delivery suppresses tumorigenesis in a murine liver cancer model. Cell 137, 1005-1017.

Krek, A., Grun, D., Poy, M.N., Wolf, R., Rosenberg, L., Epstein, E.J., MacMenamin, P., da Piedade, I., Gunsalus, K.C., Stoffel, M., Rajewsky, N., 2005. Combinatorial microRNA target predictions. Nat. Genet. 37, 495-500.

Krutzfeldt, J., Rajewsky, N., Braich, R., Rajeev, K.G., Tuschl, T., Manoharan, M., Stoffel, M., 2005. Silencing of microRNAs in vivo with 'antagomirs'. Nature 438, 685-689.

Kuilman, T., Michaloglou, C., Mooi, W.J., Peeper, D.S., 2010. The essence of senescence. Genes Dev. 24, 2463-2479.

Kumamoto, K., Spillare, E.A., Fujita, K., Horikawa, I., Yamashita, T., Appella, E., Nagashima, M., Takenoshita, S., Yokota, J., Harris, C.C., 2008. Nutlin-3a activates p53 to both down-regulate inhibitor of growth 2 and up-regulate mir-34a, mir-34b, and mir-34c expression, and induce senescence. Cancer Res. 68, 3193-3203.

Kumar, M., Lu, Z., Takwi, A.A., Chen, W., Callander, N.S., Ramos, K.S., Young, K.H., Li, Y., 2010. Negative regulation of the tumor suppressor p53 gene by microRNAs. Oncogene 30 , 843-853.
Kumar, M.S., Lu, J., Mercer, K.L., Golub, T.R., Jacks, T., 2007. Impaired microRNA processing enhances cellular transformation and tumorigenesis. Nat. Genet. 39, 673-677.

Kumar, M.S., Pester, R.E., Chen, C.Y., Lane, K., Chin, C., Lu, J., Kirsch, D.G., Golub, T.R., Jacks, T., 2009. Dicer1 functions as a haploinsufficient tumor suppressor. Genes Dev. 23, 2700-2704.

Lagana, A., Russo, F., Sismeiro, C., Giugno, R., Pulvirenti, A., Ferro, A., 2010. Variability in the incidence of miRNAs and genes in fragile sites and the role of repeats and CpG islands in the distribution of genetic material. PLoS One 5, e11166.

Lagos-Quintana, M., Rauhut, R., Lendeckel, W., Tuschl, T., 2001. Identification of novel genes coding for small expressed RNAs. Science 294, 853-858.

Lal, A., Kim, H.H., Abdelmohsen, K., Kuwano, Y., Pullmann Jr., R., Srikantan, S., Subrahmanyam, R., Martindale, J.L., Yang, X., Ahmed, F., Navarro, F., Dykxhoorn, D., Lieberman, J., Gorospe, M., 2008. p16(INK4a) translation suppressed by miR24. PLoS One 3, e1864.

Lal, A., Navarro, F., Maher, C.A., Maliszewski, L.E., Yan, N., O'Day, E., Chowdhury, D., Dykxhoorn, D.M., Tsai, P., Hofmann, O., Becker, K.G., Gorospe, M., Hide, W., Lieberman, J., 2009a. miR-24 Inhibits cell proliferation by targeting E2F2, MYC, and other cell-cycle genes via binding to "seedless" 3'UTR microRNA recognition elements. Mol. Cell. 35, 610-625.

Lal, A., Pan, Y., Navarro, F., Dykxhoorn, D.M., Moreau, L., Meire, E., Bentwich, Z., Lieberman, J., Chowdhury, D., 2009b. miR-24mediated downregulation of H2AX suppresses DNA repair in terminally differentiated blood cells. Nat. Struct. Mol. Biol. 16, 492-498.

Lambertz, I., Nittner, D., Mestdagh, P., Denecker, G., Vandesompele, J., Dyer, M.A., Marine, J.C., 2010. Monoallelic but not biallelic loss of Dicer1 promotes tumorigenesis in vivo. Cell. Death Differ. 17, 633-641.

Lamy, P., Andersen, C.L., Dyrskjot, L., Torring, N., Orntoft, T., Wiuf, C., 2006. Are microRNAs located in genomic regions associated with cancer? Br. J. Cancer 95, 1415-1418.

Laneve, P., Di Marcotullio, L., Gioia, U., Fiori, M.E., Ferretti, E., Gulino, A., Bozzoni, I., Caffarelli, E., 2007. The interplay between microRNAs and the neurotrophin receptor tropomyosinrelated kinase $C$ controls proliferation of human neuroblastoma cells. Proc. Natl. Acad. Sci. USA 104, 7957-7962.

Lanford, R.E., Hildebrandt-Eriksen, E.S., Petri, A., Persson, R., Lindow, M., Munk, M.E., Kauppinen, S., Orum, H., 2010. Therapeutic silencing of microRNA-122 in primates with chronic hepatitis C virus infection. Science 327, 198-201.

Langley, E., Pearson, M., Faretta, M., Bauer, U.M., Frye, R.A., Minucci, S., Pelicci, P.G., Kouzarides, T., 2002. Human SIR2 deacetylates p53 and antagonizes PML/p53-induced cellular senescence. EMBO J. 21, 2383-2396.

Lau, N.C., Lim, L.P., Weinstein, E.G., Bartel, D.P., 2001. An abundant class of tiny RNAs with probable regulatory roles in Caenorhabditis elegans. Science 294, 858-862.

Lawrie, C.H., Gal, S., Dunlop, H.M., Pushkaran, B., Liggins, A.P., Pulford, K., Banham, A.H., Pezzella, F., Boultwood, J., Wainscoat, J.S., Hatton, C.S., Harris, A.L., 2008. Detection of elevated levels of tumour-associated microRNAs in serum of patients with diffuse large B-cell lymphoma. Br. J. Haematol. $141,672-675$.

Le, M.T., Teh, C., Shyh-Chang, N., Xie, H., Zhou, B., Korzh, V., Lodish, H.F., Lim, B., 2009. MicroRNA-125b is a novel negative regulator of p53. Genes Dev. 23, 862-876.

le Sage, C., Nagel, R., Egan, D.A., Schrier, M., Mesman, E., Mangiola, A., Anile, C., Maira, G., Mercatelli, N., Ciafre, S.A., Farace, M.G., Agami, R., 2007. Regulation of the p27(Kip1) tumor suppressor by miR-221 and miR-222 promotes cancer cell proliferation. EMBO J. 26, 3699-3708. 
Lee, R.C., Ambros, V., 2001. An extensive class of small RNAs in Caenorhabditis elegans. Science 294, 862-864.

Lee, R.C., Feinbaum, R.L., Ambros, V., 1993. The C. elegans heterochronic gene lin-4 encodes small RNAs with antisense complementarity to lin-14. Cell 75, 843-854.

Lee, Y., Kim, M., Han, J., Yeom, K.H., Lee, S., Baek, S.H., Kim, V.N., 2004. MicroRNA genes are transcribed by RNA polymerase II. EMBO J. 23, 4051-4060.

Lee, Y.S., Dutta, A., 2007. The tumor suppressor microRNA let-7 represses the HMGA2 oncogene. Genes Dev. 21, 1025-1030.

Lehmann, U., Hasemeier, B., Christgen, M., Muller, M., Romermann, D., Langer, F., Kreipe, H., 2008. Epigenetic inactivation of microRNA gene hsa-mir-9-1 in human breast cancer. J. Pathol. 214, 17-24.

Leucci, E., Zriwil, A., Gregersen, L.H., Jensen, K.T., Obad, S., Bellan, C., Leoncini, L., Kauppinen, S., Lund, A.H. Inhibition of miR-9 de-represses HuR and DICER1 and impairs Hodgkin lymphoma tumour outgrowth in vivo. Oncogene, in press.

Levine, E., McHale, P., Levine, H., 2007. Small regulatory RNAs may sharpen spatial expression patterns. PLoS Comput. Biol. 3, e233.

Lewis, B.P., Burge, C.B., Bartel, D.P., 2005. Conserved seed pairing, often flanked by adenosines, indicates that thousands of human genes are microRNA targets. Cell 120, 15-20.

Li, J., Donath, S., Li, Y., Qin, D., Prabhakar, B.S., Li, P., 2010. miR-30 regulates mitochondrial fission through targeting p53 and the dynamin-related protein-1 pathway. PLoS Genet. 6, e1000795.

Lim, L.P., Lau, N.C., Garrett-Engele, P., Grimson, A., Schelter, J.M., Castle, J., Bartel, D.P., Linsley, P.S., Johnson, J.M., 2005. Microarray analysis shows that some microRNAs downregulate large numbers of target mRNAs. Nature 433, 769-773.

Lima, R.T., Busacca, S., Almeida, G.M., Gaudino, G., Fennell, D.A., Vasconcelos, M.H., 2011. MicroRNA regulation of core apoptosis pathways in cancer. Eur. J. Cancer 47, 163-174.

Link, A., Balaguer, F., Shen, Y., Nagasaka, T., Lozano, J.J., Boland, C.R., Goel, A., 2010. Fecal MicroRNAs as novel biomarkers for colon cancer screening. Cancer Epidemiol. Biomarkers Prev.: A Pub. Am. Assoc. Cancer Res. Cosponsored by Am. Soc. Prev. Oncol. 19, 1766-1774.

Linsley, P.S., Schelter, J., Burchard, J., Kibukawa, M., Martin, M.M., Bartz, S.R., Johnson, J.M., Cummins, J.M., Raymond, C.K., Dai, H., Chau, N., Cleary, M., Jackson, A.L., Carleton, M., Lim, L., 2007. Transcripts targeted by the microRNA-16 family cooperatively regulate cell cycle progression. Mol. Cell. Biol. 27, 2240-2252.

Liu, B., Wu, X., Liu, B., Wang, C., Liu, Y., Zhou, Q., Xu, K., 2012. MiR-26a enhances metastasis potential of lung cancer cells via AKT pathway by targeting PTEN. Biochim. Biophys. Acta 1822, 1692-1704.

Liu, C., Kelnar, K., Liu, B., Chen, X., Calhoun-Davis, T., Li, H., Patrawala, L., Yan, H., Jeter, C., Honorio, S., Wiggins, J.F., Bader, A.G., Fagin, R., Brown, D., Tang, D.G., 2011. The microRNA miR-34a inhibits prostate cancer stem cells and metastasis by directly repressing CD44. Nat. Med. 17, 211-215.

Liu, Q., Fu, H., Sun, F., Zhang, H., Tie, Y., Zhu, J., Xing, R., Sun, Z., Zheng, X., 2008. miR-16 family induces cell cycle arrest by regulating multiple cell cycle genes. Nucleic Acids Res. 36, 5391-5404.

Lize, M., Pilarski, S., Dobbelstein, M., 2010. E2F1-inducible microRNA 449a/b suppresses cell proliferation and promotes apoptosis. Cell. Death Differ. 17, 452-458.

Lopez-Serra, P., Esteller, M., 2012. DNA methylation-associated silencing of tumor-suppressor microRNAs in cancer. Oncogene 31, 1609-1622.

Lu, J., Getz, G., Miska, E.A., Alvarez-Saavedra, E., Lamb, J., Peck, D., Sweet-Cordero, A., Ebert, B.L., Mak, R.H., Ferrando, A.A., Downing, J.R., Jacks, T., Horvitz, H.R., Golub, T.R., 2005.
MicroRNA expression profiles classify human cancers. Nature 435, 834-838.

Lujambio, A., Ropero, S., Ballestar, E., Fraga, M.F., Cerrato, C., Setien, F., Casado, S., Suarez-Gauthier, A., Sanchez-Cespedes, M., Git, A., Spiteri, I., Das, P.P., Caldas, C., Miska, E., Esteller, M., 2007. Genetic unmasking of an epigenetically silenced microRNA in human cancer cells. Cancer Res. 67, 1424-1429.

Ma, L., Reinhardt, F., Pan, E., Soutschek, J., Bhat, B., Marcusson, E.G., Teruya-Feldstein, J., Bell, G.W., Weinberg, R.A., 2010. Therapeutic silencing of miR-10b inhibits metastasis in a mouse mammary tumor model. Nat. Biotech. 28, 341-347.

Ma, L., Teruya-Feldstein, J., Weinberg, R.A., 2007. Tumour invasion and metastasis initiated by microRNA-10b in breast cancer. Nature 449, 682-688.

Manfredi, J.J., 2010. The Mdm2-p53 relationship evolves: Mdm2 swings both ways as an oncogene and a tumor suppressor. Genes Dev. 24, 1580-1589.

Martello, G., Rosato, A., Ferrari, F., Manfrin, A., Cordenonsi, M., Dupont, S., Enzo, E., Guzzardo, V., Rondina, M., Spruce, T., Parenti, A.R., Daidone, M.G., Bicciato, S., Piccolo, S., 2010. A microRNA targeting dicer for metastasis control. Cell 141, 1195-1207.

Matsuoka, S., Ballif, B.A., Smogorzewska, A., McDonald 3rd, E.R., Hurov, K.E., Luo, J., Bakalarski, C.E., Zhao, Z., Solimini, N., Lerenthal, Y., Shiloh, Y., Gygi, S.P., Elledge, S.J., 2007. ATM and ATR substrate analysis reveals extensive protein networks responsive to DNA damage. Science 316, 1160-1166.

Mavrakis, K.J., Van Der Meulen, J., Wolfe, A.L., Liu, X., Mets, E., Taghon, T., Khan, A.A., Setty, M., Rondou, P., Vandenberghe, P., Delabesse, E., Benoit, Y., Socci, N.B., Leslie, C.S., Van Vlierberghe, P., Speleman, F., Wendel, H.G., 2011. A cooperative microRNA-tumor suppressor gene network in acute T-cell lymphoblastic leukemia (T-ALL). Nat. Genet. 43, 673-678.

Mayr, C., Bartel, D.P., 2009. Widespread shortening of 3'UTRs by alternative cleavage and polyadenylation activates oncogenes in cancer cells. Cell 138, 673-684.

Mayr, C., Hemann, M.T., Bartel, D.P., 2007. Disrupting the pairing between let-7 and Hmga2 enhances oncogenic transformation. Science 315, 1576-1579.

Medina, P.P., Nolde, M., Slack, F.J., 2010. OncomiR addiction in an in vivo model of microRNA-21-induced pre-B-cell lymphoma. Nature 467, 86-90.

Melo, S.A., Moutinho, C., Ropero, S., Calin, G.A., Rossi, S., Spizzo, R., Fernandez, A.F., Davalos, V., Villanueva, A., Montoya, G., Yamamoto, H., Schwartz Jr., S., Esteller, M., 2010. A genetic defect in exportin-5 traps precursor microRNAs in the nucleus of cancer cells. Cancer Cell 18, 303-315.

Melo, S.A., Ropero, S., Moutinho, C., Aaltonen, L.A., Yamamoto, H., Calin, G.A., Rossi, S., Fernandez, A.F., Carneiro, F., Oliveira, C., Ferreira, B., Liu, C.G., Villanueva, A., Capella, G., Schwartz Jr., S., Shiekhattar, R., Esteller, M., 2009. A TARBP2 mutation in human cancer impairs microRNA processing and DICER1 function. Nat. Genet. 41, 365-370.

Meng, F., Henson, R., Wehbe-Janek, H., Ghoshal, K., Jacob, S.T., Patel, T., 2007. MicroRNA-21 regulates expression of the PTEN tumor suppressor gene in human hepatocellular cancer. Gastroenterology 133, 647-658.

Mishra, P.J., Mishra, P.J., Banerjee, D., Bertino, J.R., 2008. MiRSNPs or MiR-polymorphisms, new players in microRNA mediated regulation of the cell: introducing microRNA pharmacogenomics. Cell Cycle 7, 853-858.

Mitchell, P.S., Parkin, R.K., Kroh, E.M., Fritz, B.R., Wyman, S.K., Pogosova-Agadjanyan, E.L., Peterson, A., Noteboom, J., O’Briant, K.C., Allen, A., Lin, D.W., Urban, N., Drescher, C.W., Knudsen, B.S., Stirewalt, D.L., Gentleman, R., Vessella, R.L., Nelson, P.S., Martin, D.B., Tewari, M., 2008. Circulating 
microRNAs as stable blood-based markers for cancer detection. Proc. Natl. Acad. Sci. USA 105, 10513-10518.

Mott, J.L., Kobayashi, S., Bronk, S.F., Gores, G.J., 2007. mir-29 regulates $\mathrm{Mcl}-1$ protein expression and apoptosis. Oncogene 26, 6133-6140.

$\mathrm{Mu}$, P., Han, Y.C., Betel, D., Yao, E., Squatrito, M., Ogrodowski, P. de Stanchina, E., D'Andrea, A., Sander, C., Ventura, A., 2009. Genetic dissection of the miR-17 92 cluster of microRNAs in Myc-induced B-cell lymphomas. Genes Dev. 23, 2806-2811.

Muller, P.A., Vousden, K.H., Norman, J.C., 2011. p53 and its mutants in tumor cell migration and invasion. J. Cell. Biol. 192, 209-218.

Munker, R., Calin, G.A., 2011. MicroRNA profiling in cancer. Clin. Sci. (Lond.) 121, 141-158.

Muralidhar, B., Goldstein, L.D., Ng, G., Winder, D.M., Palmer, R.D., Gooding, E.L., Barbosa-Morais, N.L., Mukherjee, G., Thorne, N.P., Roberts, I., Pett, M.R., Coleman, N., 2007. Global microRNA profiles in cervical squamous cell carcinoma depend on Drosha expression levels. J. Pathol. 212, 368-377.

Murray, A.W., 2004. Recycling the cell cycle: cyclins revisited. Cell 116, 221-234.

Neilsen, P.M., Noll, J.E., Mattiske, S., Bracken, C.P., Gregory, P.A., Schulz, R.B., Lim, S.P., Kumar, R., Suetani, R.J., Goodall, G.J., Callen, D.F., Mutant p53 drives invasion in breast tumors through up-regulation of miR-155. Oncogene, in press.

Newman, M.A., Hammond, S.M., 2010. Emerging paradigms of regulated microRNA processing. Genes Dev. 24, 1086-1092.

Ng, E.K., Chong, W.W., Jin, H., Lam, E.K., Shin, V.Y., Yu, J., Poon, T.C., Ng, S.S., Sung, J.J., 2009. Differential expression of microRNAs in plasma of patients with colorectal cancer: a potential marker for colorectal cancer screening. Gut 58 , 1375-1381.

Nishino, J., Kim, I., Chada, K., Morrison, S.J., 2008. Hmga2 promotes neural stem cell self-renewal in young but not old mice by reducing p16Ink4a and p19Arf Expression. Cell 135, 227-239.

Nittner, D., Lambertz, I., Clermont, F., Mestdagh, P., Kohler, C., Nielsen, S.J., Jochemsen, A., Speleman, F., Vandesompele, J., Dyer, M.A., Schramm, A., Schulte, J.H., Marine, J.C., 2012. Synthetic lethality between $\mathrm{Rb}, \mathrm{p} 53$ and Dicer or miR-17-92 in retinal progenitors suppresses retinoblastoma formation. Nat. Cell. Biol. 4, 958-965.

O'Donnell, K.A., Wentzel, E.A., Zeller, K.I., Dang, C.V., Mendell, J.T., 2005. c-Myc-regulated microRNAs modulate E2F1 expression. Nature 435, 839-843.

Olive, V., Bennett, M.J., Walker, J.C., Ma, C., Jiang, I., CordonCardo, C., Li, Q.J., Lowe, S.W., Hannon, G.J., He, L., 2009. miR-19 is a key oncogenic component of mir-17-92. Genes Dev. 23, 2839-2849.

Olson, P., Lu, J., Zhang, H., Shai, A., Chun, M.G., Wang, Y., Libutti, S.K., Nakakura, E.K., Golub, T.R., Hanahan, D., 2009. MicroRNA dynamics in the stages of tumorigenesis correlate with hallmark capabilities of cancer. Genes Dev. 23, 2152-2165.

Pampalakis, G., Diamandis, E.P., Katsaros, D., Sotiropoulou, G., 2010. Down-regulation of dicer expression in ovarian cancer tissues. Clin. Biochem. 43, 324-327.

Park, J.K., Kogure, T., Nuovo, G.J., Jiang, J., He, L., Kim, J.H., Phelps, M.A., Papenfuss, T.L., Croce, C.M., Patel, T., Schmittgen, T.D., 2011. miR-221 silencing blocks hepatocellular carcinoma and promotes survival. Cancer Res. 71, 7608-7616.

Park, S.M., Shell, S., Radjabi, A.R., Schickel, R., Feig, C., Boyerinas, B., Dinulescu, D.M., Lengyel, E., Peter, M.E., 2007. Let-7 prevents early cancer progression by suppressing expression of the embryonic gene HMGA2. Cell Cycle 6, 2585-2590.

Park, S.Y., Lee, J.H., Ha, M., Nam, J.W., Kim, V.N., 2009. miR-29 miRNAs activate p53 by targeting p85 alpha and CDC42. Nat. Struct. Mol. Biol. 16, 23-29.
Paroo, Z., Ye, X., Chen, S., Liu, Q., 2009. Phosphorylation of the human microRNA-generating complex mediates MAPK/Erk signaling. Cell 139, 112-122.

Peter, M.E., 2009. Let-7 and miR-200 microRNAs: guardians against pluripotency and cancer progression. Cell Cycle 8, 843-852.

Pichiorri, F., Suh, S.S., Rocci, A., De Luca, L., Taccioli, C., Santhanam, R., Zhou, W., Benson Jr., D.M., Hofmainster, C., Alder, H., Garofalo, M., Di Leva, G., Volinia, S., Lin, H.J., Perrotti, D., Kuehl, M., Aqeilan, R.I., Palumbo, A., Croce, C.M., 2010. Downregulation of p53-inducible microRNAs 192, 194, and 215 Impairs the p53/MDM2 autoregulatory loop in multiple myeloma development. Cancer Cell 18, 367-381.

Pickering, M.T., Stadler, B.M., Kowalik, T.F., 2008. miR-17 and miR-20a temper an E2F1-induced G1 checkpoint to regulate cell cycle progression. Oncogene 28, 140-145.

Polager, S., Ginsberg, D., 2009. p53 and E2f: partners in life and death. Nat. Rev. Cancer 9, 738-748.

Poliseno, L., Salmena, L., Zhang, J., Carver, B., Haveman, W.J., Pandolfi, P.P., 2010. A coding-independent function of gene and pseudogene mRNAs regulates tumour biology. Nature 465 , 1033-1038.

Pothof, J., van Gent, D.C., 2011. Spatiotemporal aspects of MicroRNA-mediated gene regulation. Adv. Exp. Med. Biol. 722, 75-85.

Pothof, J., Verkaik, N.S., van, I.W., Wiemer, E.A., Ta, V.T., van der Horst, G.T., Jaspers, N.G., van Gent, D.C., Hoeijmakers, J.H., Persengiev, S.P., 2009. MicroRNA-mediated gene silencing modulates the UV-induced DNA-damage response. EMBO J. 28, 2090-2099.

Pramanik, D., Campbell, N.R., Karikari, C., Chivukula, R., Kent, O.A., Mendell, J.T., Maitra, A., 2011. Restitution of tumor suppressor microRNAs using a systemic nanovector inhibits pancreatic cancer growth in mice. Mol. Cancer Ther. 10, 1470-1480.

Raver-Shapira, N., Marciano, E., Meiri, E., Spector, Y., Rosenfeld, N., Moskovits, N., Bentwich, Z., Oren, M., 2007. Transcriptional activation of miR-34a contributes to p53mediated apoptosis. Mol. Cell. 26, 731-743.

Reinhart, B.J., Slack, F.J., Basson, M., Pasquinelli, A.E., Bettinger, J.C., Rougvie, A.E., Horvitz, H.R., Ruvkun, G., 2000. The 21-nucleotide let-7 RNA regulates developmental timing in Caenorhabditis elegans. Nature 403, 901-906.

Resnick, K.E., Alder, H., Hagan, J.P., Richardson, D.L., Croce, C.M., Cohn, D.E., 2009. The detection of differentially expressed microRNAs from the serum of ovarian cancer patients using a novel real-time PCR platform. Gynecol. Oncol. 112, 55-59.

Rosenfeld, N., Aharonov, R., Meiri, E., Rosenwald, S., Spector, Y., Zepeniuk, M., Benjamin, H., Shabes, N., Tabak, S., Levy, A., Lebanony, D., Goren, Y., Silberschein, E., Targan, N., BenAri, A., Gilad, S., Sion-Vardy, N., Tobar, A., Feinmesser, M., Kharenko, O., Nativ, O., Nass, D., Perelman, M., Yosepovich, A., Shalmon, B., Polak-Charcon, S., Fridman, E., Avniel, A., Bentwich, I., Bentwich, Z., Cohen, D., Chajut, A., Barshack, I., 2008. MicroRNAs accurately identify cancer tissue origin. Nat. Biotech. 26, 462-469.

Sachdeva, M., Zhu, S., Wu, F., Wu, H., Walia, V., Kumar, S., Elble, R., Watabe, K., Mo, Y.Y., 2009. p53 represses c-Myc through induction of the tumor suppressor miR-145. Proc. Natl. Acad. Sci. USA 106, 3207-3212.

Saito, Y., Liang, G., Egger, G., Friedman, J.M., Chuang, J.C., Coetzee, G.A., Jones, P.A., 2006. Specific activation of microRNA-127 with downregulation of the proto-oncogene BCL6 by chromatin-modifying drugs in human cancer cells. Cancer Cell 9, 435-443.

Saj, A., Lai, E.C., 2011. Control of microRNA biogenesis and transcription by cell signaling pathways. Curr. Opin. Genet. Develop. 21, 504-510. 
Salmena, L., Poliseno, L., Tay, Y., Kats, L., Pandolfi, P.P., 2011. A ceRNA hypothesis: the Rosetta Stone of a hidden RNA language? Cell 146, 353-358.

Sampson, V.B., Rong, N.H., Han, J., Yang, Q., Aris, V., Soteropoulos, P., Petrelli, N.J., Dunn, S.P., Krueger, L.J., 2007. MicroRNA let-7a down-regulates MYC and reverts MYCinduced growth in Burkitt lymphoma cells. Cancer Res. 67, 9762-9770.

Sandberg, R., Neilson, J.R., Sarma, A., Sharp, P.A., Burge, C.B., 2008. Proliferating cells express mRNAs with shortened 3' untranslated regions and fewer microRNA target sites. Science 320, 1643-1647.

Sarkar, S., Dey, B.K., Dutta, A., 2010. MiR-322/424 and -503 are induced during muscle differentiation and promote cell cycle quiescence and differentiation by down-regulation of Cdc25A. Mol. Biol. Cell. 21, 2138-2149.

Scott, G.K., Mattie, M.D., Berger, C.E., Benz, S.C., Benz, C.C., 2006. Rapid alteration of microRNA levels by histone deacetylase inhibition. Cancer Res. 66, 1277-1281.

Seitz, H., 2009. Redefining microRNA targets. Curr. Biol. 19, 870-873.

Sherr, C.J., 1996. Cancer cell cycles. Science 274, 1672-1677.

Skog, J., Wurdinger, T., van Rijn, S., Meijer, D.H., Gainche, L., Sena-Esteves, M., Curry Jr., W.T., Carter, B.S., Krichevsky, A.M., Breakefield, X.O., 2008. Glioblastoma microvesicles transport RNA and proteins that promote tumour growth and provide diagnostic biomarkers. Nat. Cell. Biol. 10, 1470-1476.

Sotiropoulou, G., Pampalakis, G., Lianidou, E., Mourelatos, Z., 2009. Emerging roles of microRNAs as molecular switches in the integrated circuit of the cancer cell. RNA 15, 1443-1461.

Stucki, M., Clapperton, J.A., Mohammad, D., Yaffe, M.B., Smerdon, S.J., Jackson, S.P., 2005. MDC1 directly binds phosphorylated histone $\mathrm{H} 2 \mathrm{AX}$ to regulate cellular responses to DNA double-strand breaks. Cell 123, 1213-1226.

Su, X., Chakravarti, D., Cho, M.S., Liu, L., Gi, Y.J., Lin, Y.L., Leung, M.L., El-Naggar, A., Creighton, C.J., Suraokar, M.B., Wistuba, I., Flores, E.R., 2010. TAp63 suppresses metastasis through coordinate regulation of Dicer and miRNAs. Nature 467, 986-990.

Suzuki, H.I., Yamagata, K., Sugimoto, K., Iwamoto, T., Kato, S., Miyazono, K., 2009. Modulation of microRNA processing by p53. Nature 460, 529-533.

Swarbrick, A., Woods, S.L., Shaw, A., Balakrishnan, A., Phua, Y., Nguyen, A., Chanthery, Y., Lim, L., Ashton, L.J., Judson, R.L., Huskey, N., Blelloch, R., Haber, M., Norris, M.D., Lengyel, P., Hackett, C.S., Preiss, T., Chetcuti, A., Sullivan, C.S., Marcusson, E.G., Weiss, W., L'Etoile, N., Goga, A., 2010. miR$380-5 p$ represses $p 53$ to control cellular survival and is associated with poor outcome in MYCN-amplified neuroblastoma. Nat. Med. 16, 1134-1140.

Tam, W., Dahlberg, J.E., 2006. miR-155/BIC as an oncogenic microRNA. Gene. Chromosome. Cancer 45, 211-212.

Tarasov, V., Jung, P., Verdoodt, B., Lodygin, D., Epanchintsev, A., Menssen, A., Meister, G., Hermeking, H., 2007. Differential regulation of microRNAs by $\mathrm{p} 53$ revealed by massively parallel sequencing: miR-34a is a p53 target that induces apoptosis and G1-arrest. Cell Cycle 6, 1586-1593.

Tazawa, H., Tsuchiya, N., Izumiya, M., Nakagama, H., 2007. Tumor-suppressive miR-34a induces senescence-like growth arrest through modulation of the E2F pathway in human colon cancer cells. Proc. Natl. Acad. Sci. USA 104, 15472-15477.

Thorsen, S.B., Obad, S., Jensen, N.F., Stenvang, J., Kauppinen, S., 2012. The therapeutic potential of microRNAs in cancer. Cancer J. 18, 275-284.

Thum, T., Gross, C., Fiedler, J., Fischer, T., Kissler, S., Bussen, M., Galuppo, P., Just, S., Rottbauer, W., Frantz, S., Castoldi, M., Soutschek, J., Koteliansky, V., Rosenwald, A., Basson, M.A., Licht, J.D., Pena, J.T., Rouhanifard, S.H.,
Muckenthaler, M.U., Tuschl, T., Martin, G.R., Bauersachs, J., Engelhardt, S., 2008. MicroRNA-21 contributes to myocardial disease by stimulating MAP kinase signalling in fibroblasts. Nature 456, 980-984.

Toyota, M., Suzuki, H., Sasaki, Y., Maruyama, R., Imai, K., Shinomura, Y., Tokino, T., 2008. Epigenetic silencing of microRNA-34b/c and B-cell translocation gene 4 is associated with CpG island methylation in colorectal cancer. Cancer Res. 68, 4123-4132.

Trabucchi, M., Briata, P., Garcia-Mayoral, M., Haase, A.D., Filipowicz, W., Ramos, A., Gherzi, R., Rosenfeld, M.G., 2009. The RNA-binding protein KSRP promotes the biogenesis of a subset of microRNAs. Nature 459, 1010-1014.

Trang, P., Medina, P.P., Wiggins, J.F., Ruffino, L., Kelnar, K., Omotola, M., Homer, R., Brown, D., Bader, A.G., Weidhaas, J.B., Slack, F.J., 2010. Regression of murine lung tumors by the let-7 microRNA. Oncogene 29, 1580-1587.

Trang, P., Wiggins, J.F., Daige, C.L., Cho, C., Omotola, M., Brown, D., Weidhaas, J.B., Bader, A.G., Slack, F.J., 2011. Systemic delivery of tumor suppressor microRNA mimics using a neutral lipid emulsion inhibits lung tumors in mice. Mol. Ther. J. Am. Soc. Gene Ther. 19, 1116-1122.

Tsang, J.S., Ebert, M.S., van Oudenaarden, A., 2010. Genome-wide dissection of microRNA functions and cotargeting networks using gene set signatures. Mol. Cell. 38, 140-153.

Varambally, S., Cao, Q., Mani, R.S., Shankar, S., Wang, X., Ateeq, B., Laxman, B., Cao, X., Jing, X., Ramnarayanan, K., Brenner, J.C., Yu, J., Kim, J.H., Han, B., Tan, P., Kumar-Sinha, C., Lonigro, R.J., Palanisamy, N., Maher, C.A., Chinnaiyan, A.M., 2008. Genomic loss of microRNA-101 leads to overexpression of histone methyltransferase EZH2 in cancer. Science 322, 1695-1699.

Vaziri, H., Dessain, S.K., Ng Eaton, E., Imai, S.I., Frye, R.A., Pandita, T.K., Guarente, L., Weinberg, R.A., 2001. hSIR2(SIRT1) functions as an NAD-dependent p53 deacetylase. Cell 107, 149-159.

Viswanathan, S.R., Daley, G.Q., 2010. Lin28: a microRNA regulator with a macro role. Cell 140, 445-449.

Volinia, S., Calin, G.A., Liu, C.G., Ambs, S., Cimmino, A., Petrocca, F., Visone, R., Iorio, M., Roldo, C., Ferracin, M., Prueitt, R.L., Yanaihara, N., Lanza, G., Scarpa, A., Vecchione, A., Negrini, M., Harris, C.C., Croce, C.M., 2006. A microRNA expression signature of human solid tumors defines cancer gene targets. Proc. Natl. Acad. Sci. USA 103, 2257-2261.

Vousden, K.H., Lane, D.P., 2007. p53 in health and disease. Nat. Rev. Mol. Cell. Biol. 8, 275-283.

Wade, M., Wang, Y.V., Wahl, G.M., 2010. The p53 orchestra: Mdm2 and Mdmx set the tone. Trends Cell. Biol. 20, 299-309.

Wang, J., Liu, X., Wu, H., Ni, P., Gu, Z., Qiao, Y., Chen, N., Sun, F., Fan, Q., 2010. CREB up-regulates long non-coding RNA, HULC expression through interaction with microRNA-372 in liver cancer. Nucleic Acids Res. 38, 5366-5383.

Warner, D.R., Bhattacherjee, V., Yin, X., Singh, S., Mukhopadhyay, P., Pisano, M.M., Greene, R.M., 2004. Functional interaction between Smad, CREB binding protein, and p68 RNA helicase. Biochem. Biophys. Res. Commun. 324, 70-76.

Weber, B., Stresemann, C., Brueckner, B., Lyko, F., 2007. Methylation of human microRNA genes in normal and neoplastic cells. Cell Cycle 6, 1001-1005.

Wee, E.J., Peters, K., Nair, S.S., Hulf, T., Stein, S., Wagner, S., Bailey, P., Lee, S.Y., Qu, W.J., Brewster, B., French, J.D., Dobrovic, A., Francis, G.D., Clark, S.J., Brown, M.A., 2012 Mapping the regulatory sequences controlling 93 breast cancer-associated miRNA genes leads to the identification of two functional promoters of the Hsa-mir-200b cluster, methylation of which is associated with metastasis or 
hormone receptor status in advanced breast cancer. Oncogene 31, 4182-4195.

Welch, C., Chen, Y., Stallings, R.L., 2007. MicroRNA-34a functions as a potential tumor suppressor by inducing apoptosis in neuroblastoma cells. Oncogene 26, 5017-5022.

Wightman, B., Ha, I., Ruvkun, G., 1993. Posttranscriptional regulation of the heterochronic gene lin-14 by lin- 4 mediates temporal pattern formation in C. elegans. Cell 75, 855-862.

Woods, K., Thomson, J.M., Hammond, S.M., 2007. Direct regulation of an oncogenic micro-RNA cluster by E2F transcription factors. J. Biol. Chem. 282, 2130-2134.

Wu, S., Huang, S., Ding, J., Zhao, Y., Liang, L., Liu, T., Zhan, R., He, X., 2010. Multiple microRNAs modulate p21Cip1/Waf1 expression by directly targeting its 3' untranslated region. Oncogene 29, 2302-2308.

Wurdinger, T., Tannous, B.A., Saydam, O., Skog, J., Grau, S., Soutschek, J., Weissleder, R., Breakefield, X.O., Krichevsky, A.M., 2008. miR-296 regulates growth factor receptor overexpression in angiogenic endothelial cells. Cancer Cell 14, 382-393.

Wynendaele, J., Bohnke, A., Leucci, E., Nielsen, S.J., Lambertz, I., Hammer, S., Sbrzesny, N., Kubitza, D., Wolf, A., Gradhand, E., Balschun, K., Braicu, I., Sehouli, J., Darb-Esfahani, S., Denkert, C., Thomssen, C., Hauptmann, S., Lund, A., Marine, J.C., Bartel, F., 2010. An illegitimate microRNA target site within the 3' UTR of MDM4 affects ovarian cancer progression and chemosensitivity. Cancer Res. 70, 9641-9649.

Xiao, C., Srinivasan, L., Calado, D.P., Patterson, H.C., Zhang, B., Wang, J., Henderson, J.M., Kutok, J.L., Rajewsky, K., 2008. Lymphoproliferative disease and autoimmunity in mice with increased miR-17-92 expression in lymphocytes. Nat. Immunol. 9, 405-414.

Xiao, J., Lin, H., Luo, X., Wang, Z., 2011. miR-605 joins p53 network to form a p53:miR-605:Mdm2 positive feedback loop in response to stress. EMBO J. 30, 524-532.

Yamakuchi, M., Ferlito, M., Lowenstein, C.J., 2008. miR-34a repression of SIRT1 regulates apoptosis. Proc. Natl. Acad. Sci. USA 105, 13421-13426.
Yamakuchi, M., Lotterman, C.D., Bao, C., Hruban, R.H., Karim, B., Mendell, J.T., Huso, D., Lowenstein, C.J., 2010. P53-induced microRNA-107 inhibits HIF-1 and tumor angiogenesis. Proc. Natl. Acad. Sci. USA 107, 6334-6339.

Yamakuchi, M., Lowenstein, C.J., 2009. MiR-34, SIRT1 and p53: the feedback loop. Cell Cycle 8, 712-715.

Yan, H.L., Xue, G., Mei, Q., Wang, Y.Z., Ding, F.X., Liu, M.F., Lu, M.H., Tang, Y., Yu, H.Y., Sun, S.H., 2009. Repression of the miR-17-92 cluster by 553 has an important function in hypoxia-induced apoptosis. EMBO J. 28, 2719-2732.

Yang, X., Feng, M., Jiang, X., Wu, Z., Li, Z., Aau, M., Yu, Q., 2009. miR-449a and miR-449b are direct transcriptional targets of E2F1 and negatively regulate pRb-E2F1 activity through a feedback loop by targeting CDK6 and CDC25A. Genes Dev. 23, 2388-2393.

Yi, R., Poy, M.N., Stoffel, M., Fuchs, E., 2008. A skin microRNA promotes differentiation by repressing 'stemness'. Nature 452, 225-229.

Yu, Z., Li, Z., Jolicoeur, N., Zhang, L., Fortin, Y., Wang, E., Wu, M., Shen, S.H., 2007. Aberrant allele frequencies of the SNPs located in microRNA target sites are potentially associated with human cancers. Nucleic Acids Res. 35, 4535-4541.

Yu, Z., Wang, C., Wang, M., Li, Z., Casimiro, M.C., Liu, M., Wu, K., Whittle, J., Ju, X., Hyslop, T., McCue, P., Pestell, R.G., 2008. A cyclin D1/microRNA 17/20 regulatory feedback loop in control of breast cancer cell proliferation. J. Cell. Biol. 182, 509-517.

Zhang, J., Sun, Q., Zhang, Z., Ge, S., Han, Z.G., Chen, W.T. Loss of microRNA-143/145 disturbs cellular growth and apoptosis of human epithelial cancers by impairing the MDM2-p53 feedback loop. Oncogene, in press.

Zhang, X., Wan, G., Berger, F.G., He, X., Lu, X., 2011. The ATM kinase induces microRNA biogenesis in the DNA damage response. Mol. Cell. 41, 371-383.

Zhu, D.X., Fan, L., Lu, R.N., Fang, C., Shen, W.Y., Zou, Z.J., Wang, Y.H., Zhu, H.Y., Miao, K.R., Liu, P., Xu, W., Li, J.Y., 2012. Downregulated Dicer expression predicts poor prognosis in chronic lymphocytic leukemia. Cancer Sci. 103, 875-881. 